\title{
Challenges in Access to Urban Land for Business Activities under Ethiopian Law: Between Oligarchy and Broad-based Private Sector
}

\begin{abstract}
Various restrictions in Ethiopia's urban land law have adversely affected the availability, transferability and tenure security of land-use rights for business premises. These legal and administrative challenges have led to urban land lease tender price hikes that are not affordable to the majority of economic actors in the private sector. The gaps in land information and land governance exacerbate the challenges in the realms of availability, transferability and tenure security. Such land-use right market imperfections are susceptible to economic rent seeking, resource capture and land speculation. Unearned windfall income for persons involved in resource capture, the difficulties encountered by many businesspersons in loan repayments for land lease and construction, urban land lease tender rates and rising business premise rental rates corrode rather than nurture broad-based value adding economic activities. This article examines the Ethiopian legal regime and urban land governance in light of the challenges they create in the availability, transferability and affordability of access to urban land for business activities. There is thus the need to address these challenges and enhance tenure security in order to facilitate the emergence and coalescence of a strong middle class and broadbased private sector in lieu of a nascent oligarchy of the nouveau riche (the new rich) which is in the course of ascending onto its dreamland, inter alia, through resource capture attributable to various restrictions against wider access to urban land.
\end{abstract}

Elias N. Stebek *

\section{Key terms}

Access to urban land, land-use rights, land lease, urban land law, Ethiopia

DOI http://dx.doi.org/10.4314/mlr.v9i1.2

\section{Introduction}

African Union Agenda 2063 has espoused a visionary transformational framework. It aspires that by 2063 "African countries will be amongst the best

\footnotetext{
* Elias N. Stebek (LL.B, LL.M, PhD), Associate Professor, St. Mary’s University, School of Graduate Studies. An earlier version of this article was part of an unpublished research paper titled "Access to Urban Land for Private Sector Development in Ethiopia" (Dated June 9, 2015) which was submitted to Private Sector Development Hub, Ethiopian Chamber of Commerce and Sectoral Associations.
} 
performers in global quality of life measures." This envisages "strategies for inclusive growth, job creation, increasing agricultural production; investments in science, technology, research and innovation; gender equality, youth empowerment and the provision of basic services including health, nutrition, education, shelter, water and sanitation." "Ethiopia shares these aspirations.

Ethiopia aspires to join the category of middle income countries as of the year 2025. This envisages business environment which is conducive to value adding economic pursuits, saving, investment, enhanced job creation and sustainable development. These pursuits not only aim at 'growth', but also its sustainability which, in the avenue of sustainable economic benefits, envisages significant job creation with decent levels of real income, fixed capital formation (which varies from foot-loose 'investments') and steadily improving social well-being through inclusive growth and poverty alleviation.

Ethiopia's developmental aspirations and pursuits for the years and decades ahead envisage agents of such transformation. As good practices throughout the world have proven, innovation, creativity, motivation, competence, sustained efforts and integrity are among the cornerstones of structural transformation which can be nurtured and honed at the grassroots thereby rendering the private sector a major change agent. It is under such a setting that economically empowered citizens can pursue rational (i.e., informed and morally responsible) self-interest within a framework of public interest and the common good. This requires the alleviation of various constraints including inadequate access to urban land and the restrictions in its transferability. The private sector can hardly play its role in value creation, competitiveness, and economic development in the absence of such grassroots empowerment.

There are various challenges in access to urban land in Ethiopia which adversely affect the business environment. They, inter alia, include (a) land market imperfections due to the mono-route features of urban land provision mainly by municipalities, (b) challenges in lease tender and allotment processes, (c) the breadth and security of lease rights, (d) the transferability of lease rights, (e) the right to use land rights as collaterals for bank financing, and (f) gaps in land information to the public including information about relatively predictable lease price ranges. Other issues of concern relate to institutional fragmentation in land management, incoherent practices of municipal branches of city administrations such as Addis Ababa and the challenges of the legal regime's susceptibility to opportunity grabs by speculators and corrupt office holders.

\footnotetext{
1 African Union, Agenda 2063: The Africa We Want, $2^{\text {nd }}$ Ed, Popular Version, page 3. Available at $<$ http://agenda2063.au.int/en/sites/default/files/agenda2063_popular_version_05092014_E N.pdf>, Last visited 22 January 2015.
} 
This article examines various laws, regulations and directives on land lease in light of the opportunities and challenges with regard to access to urban land for business activities. It addresses the major policy, legal and administrative challenges encountered by the business community in the process of accessing, utilizing and transferring urban land-use rights. This, inter alia, includes: the challenges with regard to (a) inadequate diversity in modalities of accessing urban land and restrictions in tenure security; (b) unaffordable lease tenders for urban land lease holding, and (c) the level of land information and governance. Particular attention is given to the Unban Land Lease Proclamation No. 721/2011, Urban Landholding Registration Proclamation No. 818/2014, Draft Urban Land Lease Model Regulations (2004 EC), Urban Land Lease Regulations No. 49/2004 EC issued by Addis Ababa City Administration, and other relevant regulations and directives.

The first three sections of the article focus on the legal regime on access to urban land including its elements of tenure security, use and consistent treatment. The fourth and fifth sections deal with challenges in access to urban land and the transferability of rental business premises. Challenges related with access to urban land are further discussed in the sixth and seventh sections which briefly address the issues of rising lease tender prices, challenges in affordability and corruption. The eighth section briefly states observations on various clusters of interest in the private sector, followed by concluding reflections on the way forward.

\section{The Legal Framework on Accessing Urban Land for Business Activities in Ethiopia}

Four key factors are suggested by Muir \& Shen, ${ }^{2}$ that determine access to land for business activities, namely: access, security, use and consistency of treatment. With some taxonomic adjustments, these indicators are used in this article to examine Ethiopia's urban land laws. These key factors are not however, considered as a rigid framework in this article but merely serve as an indicative roadmap (with some adjustments) in the first three sections. The first indicator (access) is discussed in this section while the second indicator (security) is discussed in Section 2 under a broader title: 'Scope of tenure and its security in urban land'. The third and fourth indicators of access to land (i.e. use and consistency in treatment) are highlighted in Section 3.

One of the four indicators of 'access to land' stated in Muir \& Shen is 'access' which involves the questions: "Is the land I need available? If so, from

\footnotetext{
${ }^{2}$ Russell Muir and Xiaofang Shen (2005), "Land Markets: Improving Access to Land and Buildings by Investors", FIAS World Bank Group, October 2005.
} 
whom, at what price, and on what terms? How long will it take?" These themes of availability, the terms and price of lease and the duration for obtaining landholding titles need to be examined.

\subsection{Availability of urban land and the number of suppliers of land-related rights}

One of the factors that determine access to urban land is its availability in landrelated markets. ${ }^{3}$ According to Article 40(3) of the Constitution of the Federal Democratic Republic of Ethiopia, land ownership "is exclusively vested in the State and peoples of Ethiopia." The provision further stipulates that "Land is the common property of the Nations, Nationalities and Peoples of Ethiopia and shall not be subject to sale or to other means of exchange." Article 40(6) of the Constitution recognizes "the right of private investors to the use of land on the basis of payment arrangements established by law" whose particulars shall be determined by law. The entity that avails land is thus the state as determined by the relevant laws. ${ }^{4}$ The land use rights recognized under the Constitution entail ownership rights over immovables that are constructed on the land, as enshrined in Article 40(7) of the Constitution which provides:

Every Ethiopian shall have the full right to the immovable property he builds and to the permanent improvements he brings about on the land by his labour or capital. This right shall include the right to alienate, to bequeath, and, where the right of use expires, to remove his property, transfer his title, or claim compensation for it. Particulars shall be determined by law.

The supply side in the availability of access to land and business premises thus includes owners of immovable property who are entitled to alienate their property through sale and other modalities. As land is inseparable from the building, one can argue that the owner of the building shall naturally own the use right of the land on which the house is built. There can also be an argument that neither private land ownership nor private land-use right ownership is recognized under Ethiopia's current laws (other than usufruct). However, it is to be noted that public ownership of land does not necessarily preclude private ownership of land-use rights ${ }^{5}$ in favour of landholders.

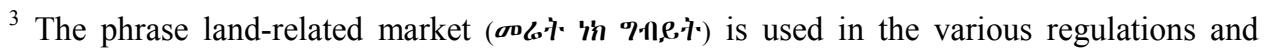
directives. See, for example, the preamble of the Urban Land Lease Regulations No. 49/2004 EC issued by Addis Ababa City Administration.

${ }^{4}$ For details regarding the problems in the scope of the land use rights embodied in various laws, see ibid.

${ }^{5}$ For example, land use rights in China's land law are referred to as ownership over the land use rights. See the Property Rights Law of the People's Republic of China, adopted at the 5th Session of the 10th National People's Congress of the People's Republic of China on March 16, 2007, and effective on October 1, 2007.
} 
Based on personal observations of this author and taxonomic reflections on the modalities of access in Addis Ababa, the following categories can be considered as modes of access to urban land for economic activities in the context of Addis Ababa:

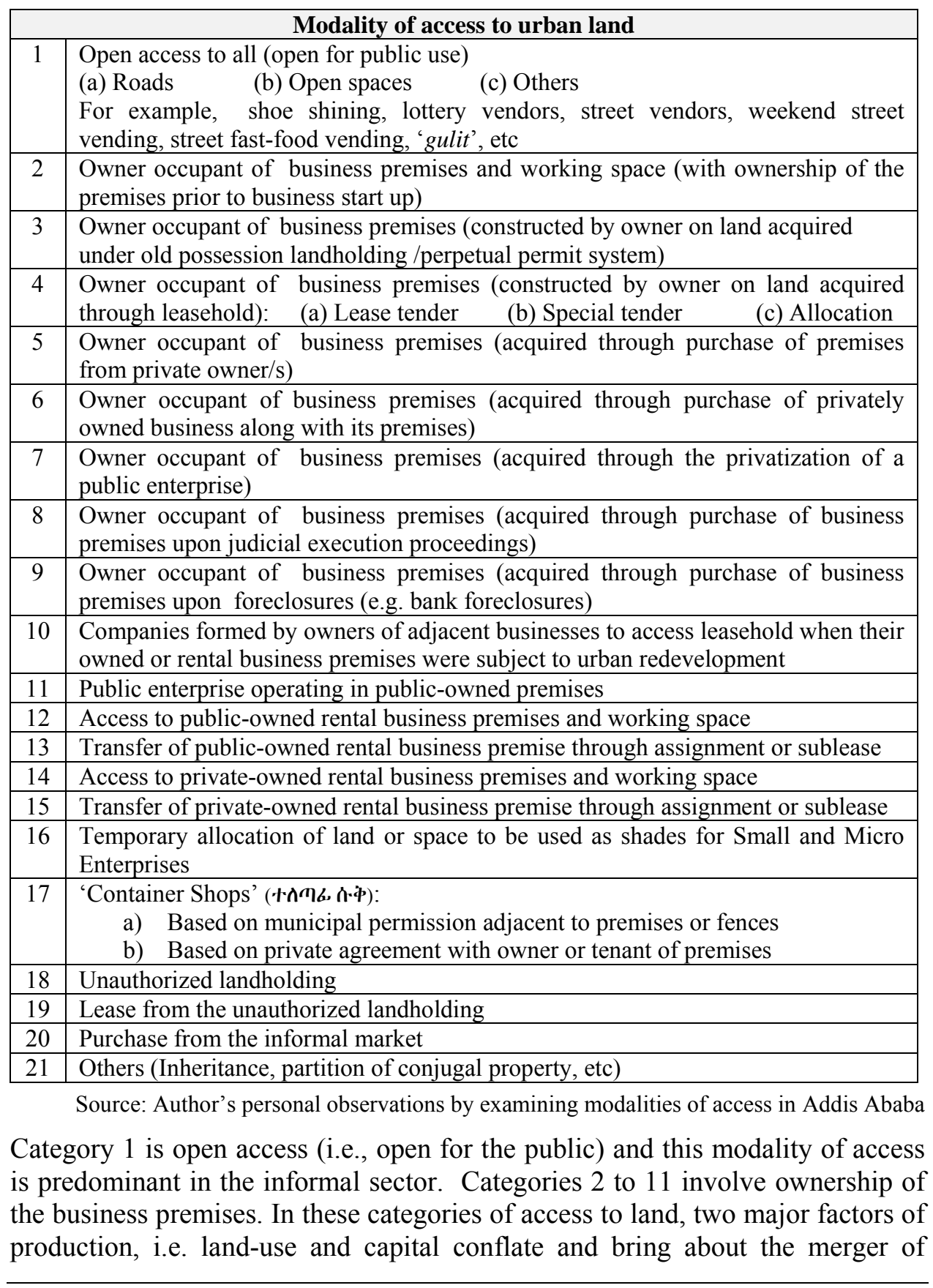


profit and the amount that could have been paid as rent. ${ }^{6}$ At times, a business entity which, in real terms is uncompetitive in comparison with other similar entities (which conduct their production of goods and/or services in rental premises), may be misled by figures which overstate its economic performance owing to non-payment of rent.

Categories 12 to 15 represent modalities of access in modern business. As real estate development is a distinct sphere of engagement, most modern economic activities are expected to focus on undertaking business activities as such, and ownership of the business premises is not usually the norm. Ownership of business premises is not thus a sine qua non condition for access to urban land. Although there are steadily rising push factors to operate in owner-occupied buildings or owner-occupied work space in Addis Ababa and other Ethiopian urban centres, this trend cannot be attributed to the inherent nature of business activities, but to various realities such as volatile rental rates, scarce supply of business premises, restrictions in sub-letting business premises and other factors.

Categories 16 and 17 are temporary modalities of access to land that are flexible in allocation and termination. They target at supporting the pursuits of micro and small enterprises in their pursuits of providing goods and services and meanwhile alleviate the problems of unemployment. The categories stated under numbers 18 to 19 refer to business premises related with settings such as unauthorized landholding and peri-urban informal transactions. This is, however, different from authorized but undocumented (w's: haq) landholding which is mainly attributable to delay in land titling processes.

The substantive laws that constitute the legal framework in the operation of the modalities stated above are mainly the 1995 Constitution, the 1960 Civil Code, the 1960 Commercial Code, Lease Proclamation 721/2011 and various regulations and directives. However, our discussion focuses on the Lease Proclamation and the regulations and directives issued toward its implementation.

The preamble of the Urban Lands Lease Holding Proclamation No. 721/2011 (hereinafter the Lease Proclamation) states the continuous and increasing "demand for urban land" that requires an appropriate administration which is "efficient and responsive to land resources demand". ${ }^{7}$ It also underlines the need for "the prevalence of good governance" as "a foundational institutional requisite for the development of an efficient, effective, equitable and well

\footnotetext{
${ }^{6}$ The challenge in such situations is the mix-up of the rent and profit aspects of the income, thereby bringing about the potential for overstating profitability and competitiveness of business undertakings.

${ }^{7}$ Proclamation No. $721 / 2011$, para 2 of the preamble.
} 
functioning land and landed property market, the sustenance of robust free market economy and for building transparent and accountable land administration system that ensures the rights and obligations of the lessor and the lessee". 8

The provisions of the Lease Proclamation and the subsequent regulations and directives that have been issued should thus be applied and interpreted with the purpose and rationale enshrined in the preamble of the proclamation. The paragraphs indicated above embody the following elements:

a) the need to address the continuous and increasing demand for urban land;

b) the need for efficient administrative framework responsive to land resources demand; and

c) the need for good governance which require:

- the development of an efficient, effective, equitable and well functioning land and landed property market,

- the sustenance of robust free market economy, and

- building transparent and accountable land administration system that ensures the rights and obligations of the lessor and the lessee.

The key concerns that arise in relation with these overarching principles enshrined in the rationale of the Lease Proclamation relate to the availability of urban land commensurate with increasing demand, the price involved in the acquisition of access, and the duration taken in the process of obtaining land. Addressing the increasing demand for urban land requires ease in transferability so that multi-track land markets can enhance the supply side of available urban land. As the following sections indicate, the Lease Proclamation and other laws have, however, restricted the domains of transferability, security and tenure thereby narrowing down the supply side of urban land-use rights.

This steadily entrenches mono-route urban land supplies and, contrary to the aspirations of the preamble of the Lease Proclamation, widens the gap between the supply side in land-related markets and the steadily increasing demand for urban land. As land is inelastic, monopoly of its supply rather worsens the imperfections in the market. It is rather enhancing the transferability of access to premises or work space in the forms of sale, lease, sub-lease, assignment, stock contribution, etc that can boost the supply side in land markets.

\subsection{The legal framework on terms, process, lease price and duration toward titles}

This heading focuses on the terms of lease through tender and allotment, the process involved in these modes of lease, the normative and institutional framework relevant for the determination of lease price and the duration

\footnotetext{
${ }^{8}$ Id., para 3.
} 
required for landholding titles. The evaluation of the themes in terms of effectiveness of the terms and affordability of lease price will be addressed in Sections 4 and 6.

\subsubsection{Terms of lease: tender and allotment}

The fundamental principles of lease are stipulated under Articles 4 to 15 of the Lease Proclamation. Article 4 identifies the terms of access, according to which access to land involves the right to use urban land by lease. ${ }^{9}$ This provision states two modalities of lease, namely (a) lease tender which reflects the prevailing transaction value of land ${ }^{10}$ and 'urban land delivery system' (allotment) that gives "priority to the interests of the public and urban centres to ensure rapid urban development and equitable benefits of citizens" thereby ensuring "the sustainability of the country's development". ${ }^{11}$

Articles 8 to 11 of the Lease Proclamation embody provisions on lease tender, and they deal with the urban lands prepared for tender, ${ }^{12}$ information about the urban land prepared for tender, ${ }^{13}$ the duty of the relevant bodies to publicize their annual plans of urban land supply for tender and promptly observe the same ${ }^{14}$ and the tender process. ${ }^{15}$ The second category of land assignment, i.e., allotment is enshrined under Articles 12 and 13. Article 12 allows the cabinet of regions or city administrations to allot land to:

a) office premises or budgetary government entities;

b) social service institutions run by government or charitable organizations;

c) public residential housing construction and government approved selfhelp housing constructions;

d) places of worship and religious organizations;

e) manufacturing industries;

f) use of embassies and international organizations as per agreements entered into with the government; [and]

g) projects having special national significance and considered by the president of the region or the mayor of the city and referred to the cabinet. ${ }^{16}$

${ }^{9}$ Id., Art. 4(1); see also Article 5 which prohibits land possession other than lease holding and Article 6 which deals issues related with the conversion of old possessions to leasehold.

${ }^{10}$ Id., Art. 4(3).

${ }^{11}$ Id., Art. 4(4), see also Article 7(2).

${ }^{12}$ Id., Art. 8.

${ }^{13}$ Id., Art. 9.

${ }^{14}$ Id., Art. 10.

${ }^{15}$ Id., Art. 11.

${ }^{16}$ Id., Art. 12(1). 


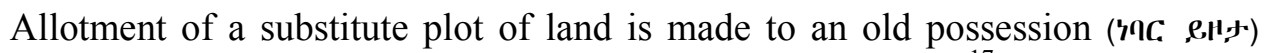
landholder who is displaced due to urban renewal program. ${ }^{17}$ With regard to tenants of public-owned rental houses, the Lease Proclamation makes a distinction between residential houses and business premises. If a tenant of public-owned business premise is displaced due to urban renewal program, the

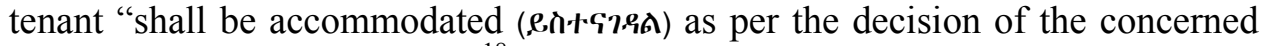
region or city administration". ${ }^{18}$ This is too general and its realization seems to depend upon the decision of the region or city administration rather than clearly articulated entitlement.

On the other hand, the Lease Proclamation entitles tenants of public-owned rental residential houses in Addis Ababa to "facilitated purchase of a condominium housing unit" if the tenant is "displaced due to urban renewal program". ${ }^{19}$ The entitlement of displaced tenants in the second chartered city in Ethiopia, i.e. Dire Dawa and in all other urban centres in Ethiopia is stipulated under the same provision (Article 12) which provides the following:

A lawful tenant of government or kebele owned residential house in a region or Dire Dawa shall be entitled to allotment of residential plot of land

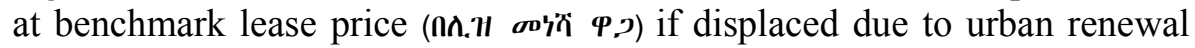
program and could not be provided with access to substitute housing; provided, however, that he shall deposit money, as determined by the appropriate body, in a blocked bank account to show his financial position. ${ }^{20}$

The terms of assignment of urban land through tender or allotment envisage two administrative requirements embodied in Article 4 of the Proclamation, namely adherence to "the principles of transparency and accountability" and, in effect, "preventing corrupt practices and abuses to ensure impartiality in the process". ${ }^{21}$ To this end, the Proclamation envisages the preparation and issuance of model regulations, directives and manuals for the implementation of the Proclamation by the Ministry of Urban Development and Construction.

The Ministry has prepared a model regulation ${ }^{22}$. With regard to access, the draft model regulation reiterates the principle that access to landholding shall solely be based on lease ${ }^{23}$ which will have two modalities, i.e. lease tender and

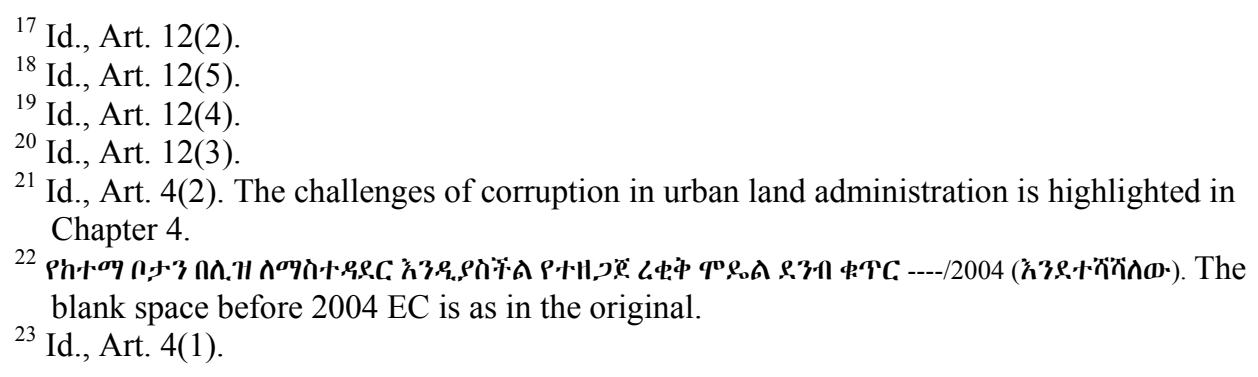


allotment. $^{24}$ The Draft Model Regulations indicates the circumstances that lead to the conversion of old possessions to lease hold ${ }^{25}$ and the conditions of transfer which do not bring about such conversion. ${ }^{26}$

\subsubsection{Regulations, Directives and Manuals}

According to Article 33(2) of the Lease Proclamation, "Regions and city administrations shall have the powers and duties to issue regulations and directives necessary for the implementation of [the] Proclamation." Accordingly, Addis Ababa City Administration, Land Management Bureau has issued the following regulations on Ginbot $16^{\text {th }} 2004$ Ethiopian Calendar $(24$ May 2012) shortly after the enactment of the Lease Proclamation on $28^{\text {th }}$ November 2011.

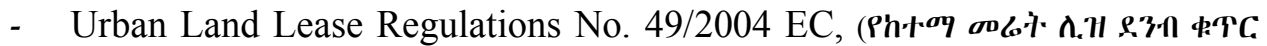
$12 / 2004)$

- Urban Land Lease Implementation Directive No. 12/2004 EC (Ph中, oq on

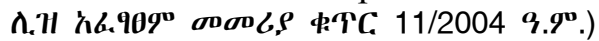

- Land Holding Administration Services Directive No. 12/2004 EC (P, \& \$

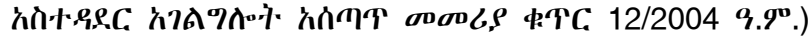

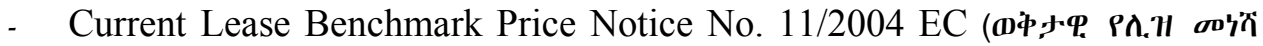

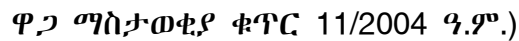

Moreover, Addis Ababa City Administration, Land Management Bureau announced the approval of three directives by the Addis Ababa City Administration cabinet on Miazia 9 and 16, 2006 EC (17 April and 26 April 2014) and these directives are effective since Ginbot $1^{\text {st }} 2006$ (9 May, 2014). The directives deal with undocumented land holdings, ${ }^{27}$ unauthorized land holdings ${ }^{28}$, and the compensation and allocation of substitute land upon expropriation for public interest. ${ }^{29}$ A manual for the implementation of undocumented land holdings $^{30}$ has also been issued by the Addis Ababa City

${ }^{24}$ Id., Art. 4(2).

${ }^{25}$ Id., Art. 7.

${ }^{26}$ Id., Art. 8.

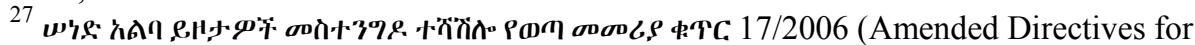
Undocumented land holdings, Directive No. 17/2006 EC).

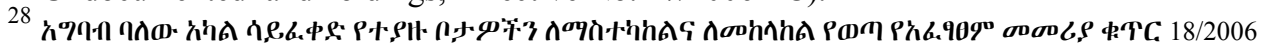
Directives to Rectify and Control unauthorized land holdings (Directive No. 18/2006 EC).

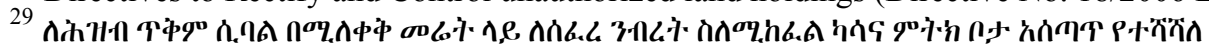

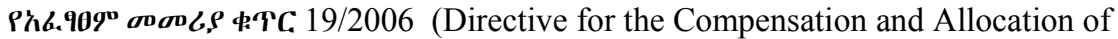
Substitute Land upon Expropriation for Public Interest ((Directive No. 19/2006 EC).

${ }^{30}$ העיל: 3/2007 (Manual for the Implementation of Undocumented Landholdings (Manual No. 3/2007 EC). 
Administration, Land Development Management Bureau, in November 2014 ( 1.96 : 2007 9.90.).

Reference to the preamble of Urban Land Lease Regulations No. 49/2004 EC issued by Addis Ababa City Administration enables us to observe the underlying spirit of the Regulations. It, inter alia, states the following as core grounds for the enactment of Proclamation No. 721/2011:

a) Leaseholds on which no construction is made or with meager construction (below the level required) were being transferred to third parties thereby facilitating rent seeking; ${ }^{31}$

b) The types and methods of lease transfer were so wide thereby opening

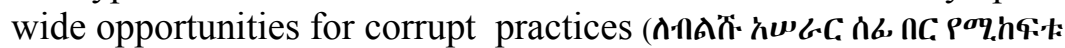

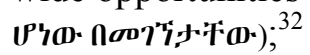

c) Separate administration of perpetual permit system ( $\left.\mathbf{9}^{\mathbf{C}} \mathbf{6} \boldsymbol{*}\right)$ and leasehold in the urban land holding system has created variation in the market value. ${ }^{33}$

According to the preamble of the Urban Land Lease Regulations No. 49/2004 EC, rectifying the gaps in the law including the ones mentioned above is the rationale for the enactment of the Lease Proclamation. The Regulation reiterates and clarifies the terms of access to urban land and the determination of the price of lease.

Article 2(4) of the Lease Proclamation defines lease tender as "a modality of transferring lease of urban land to a bid winner fulfilling the competition requirements issued based on the role of market competition of urban land tenure." Even though the Urban Land Lease Regulations No. 49/2004 EC does not have an English Version, ${ }^{34}$ the definition of lease embodied in the Proclamation is identical with the definition under the Amharic version of Article 12(12) of the Regulations. However, Article 12(13) of the Regulations renders more clarification to the second variety of tender, 'special tender' (AR. ณ८;) which refers to the lease applicable to the entities and services covered under Article11, sub-Articles 7 and 8 of the Lease Proclamation.

According to Article 11(7) of the Lease Proclamation, entitlement to special tender applies to "higher education institutions, hospitals, health research institutions, four star and above hotels, and mega real estate developments, to be undertaken by the private sector." While Article 11(4) of the Lease Proclamation requires the cancellation of bid "if less than three bidders

\footnotetext{
${ }^{31}$ Urban Land Lease Regulations No. 49/2004 EC, preamble, abridged translation.

${ }^{32}$ Ibid.

${ }^{33}$ Ibid.

${ }^{34}$ Unlike various Regulations enacted by the Addis Ababa City Council this Regulations is not enacted in Addis Negari (The Official Gazette for laws made by the City Administration).
} 
participate in the first round of tender", Article 11(8) waives this requirement where the bid applies to a business stated under Article 11(7). It allows the assignment of land through tender process, even to a sole bidder where the project falls under Article 11(7), provided that it has the "capability to implement the development project [as] verified by the relevant body".

\subsubsection{The lease process}

The lease process involves four phases that precede the lease tender. The first phase involves the preparation of land for tender by making sure that the lands "are free form legal claims of any party", "are prepared in conformity with the urban plan", "have access to infrastructure", "are parceled, delineated, assigned with unique parcel identification numbers", and "have the plans and fulfill other necessary preconditions". ${ }^{35}$

The second phase relates to information about land prepared for tender. The information should contain the land grade, the lease benchmark price and other pertinent data. ${ }^{36}$ The information should further include development program and action plan where "the urban land prepared requires a special development program and implementation action plan". ${ }^{37}$ The publicity of tender plans constitute the third phase, and this requires the relevant authorities to take into account "demand for urban land and development priorities" and "publicize their annual plans indicating the quantity of urban land" that will be offered for tender, and also make this information "easily accessible to the public". ${ }^{38}$ The fourth phase in the process refers to the "timely supply of urban land in accordance with the plans publicized". ${ }^{39}$

It is the duty of the appropriate public entity to ascertain that "the tender process is implemented in a manner that secures the appropriate price of the land following the rules of transparency and accountability". ${ }^{40}$ To this end, the lease process starts with the advertising of lease tender by the appropriate body and this involves putting forthwith bid documents on sale. ${ }^{41}$ The requirement that the sale of the bid documents should be accessible to everyone willing to bid and $^{42}$ the need for a minimum number of three bidders ${ }^{43}$ are enshrined in Article 11 of the Lease Proclamation, after which "[t]he highest bidder shall be declared a winner" on the basis of bid price and the amount of advance payment

\footnotetext{
${ }^{35}$ Lease Proclamation, Article 8(1).

${ }^{36}$ Id., Art. 9(1).

${ }^{37}$ Id., Art. 9(2).

${ }^{38}$ Id., Art. 10(1).

${ }^{39}$ Id., Art. 10(2).

${ }^{40}$ Id., Art 8(2).

41 Id., Art. 11(1).

${ }^{42}$ Id., Art. 11(2).

${ }^{43}$ Id., Art. 11(2).
} 
offered. ${ }^{44}$ And finally, the "list of winners with the details of their scores shall be made public on a notice board". 45 The process of allotment is also stated in Articles 12 and 13 .

Articles 8 to 19 of the Urban Land Lease Regulations No. 49/2004 EC deal with the lease process. The issues include publicity of land information available for lease tender (Arts 8, $10 \& 11$ ), the processes of lease tender and special lease tender (Art 9), content and availability of bid documents (Art 12), bid bonds

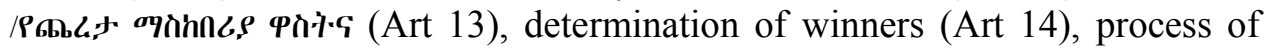
approval (Arts $15 \& 16$ ), and other issues related with the lease tender process (Arts 17-19). Articles 20 to 22 of the Regulations provide for the process of allotment in accordance with Articles 12 and 13 of the Lease Proclamation. The Urban Land Lease Implementation Directive No. 11/2004 EC provides for further details with regard to the process of lease tender (Articles 8 to 19) and allotment (Articles 20 to 23).

Although Article 18(2)(b) of the Lease Proclamation ${ }^{46}$ does not expressly indicate the beneficiaries of short-term lease (for a period not exceeding five years), Article 23 of the Urban Land Lease Regulations No. 49/2004 EC entitles the following economic activities short-term lease:

a) Production, sale or display of construction materials (Art. 23/1/b);

b) Storage of machinery and equipment during construction (Art. 23/1/c);

c) Quarries and equipment necessary for quarrying (Art. 23/1/d);

d) Billboards (Art. 23/1/e);

e) Micro and Small Enterprises for the purpose of various services or production (Art. 23/1/f).

In addition to these activities, Article 23(1)(b) of the Regulations considers the fifteen-year term allowed to urban agriculture (under Article 18(1)(a)(2) of the Lease Proclamation) as short-term lease.

\subsubsection{Price and period of payment}

Plots of urban land offered for lease tender have a benchmark price the valuation of which "will be determined on the basis of the objective conditions of each urban centre in accordance with regulations issued by the respective regions and city administrations". 47 The amount of the benchmark price varies

\footnotetext{
${ }^{44}$ Id., Art. 11(5).

${ }^{45}$ Id., Art. 11(6).

${ }^{46}$ The provision reads, "A ceiling of five years or lease period shall be applicable to shortterm economic and social activities intended to be carried out on urban lands not designated for immediate development use. Such lease period may be reviewed for the same period of time where it is necessary."

${ }^{47}$ Lease Proclamation No. 721/2011, Art. 14(1).
} 
for different locations, ${ }^{48}$ and it "shall be updated at least every two years to reflect current conditions". ${ }^{49}$ The period of payment takes into account the payback period of the investment ${ }^{50}$ upon down payment of not less than $10 \%$ of the total lease amount to be determined by the region or the city. ${ }^{51}$ The remaining balance "shall be paid on the basis of equal annual instalments during the payment term" 52 along with interest based on the prevailing rates charged by the Commercial Bank of Ethiopia on loans. ${ }^{53}$ The determination of price and time of payment are further elaborated in Articles 27 to 31 of the Urban Land Lease Regulations No. 49/2004 EC.

Specific benchmark prices for lease are issued under Current Lease Benchmark Price Notice No. 1/2004 EC. The bench mark prices (effective from Ginbot $19^{\text {th }} 2004$ EC, i.e. 27 May 2012) are classified into three zones and fourteen categories. While zones 1 and 2 have five categories each, the third zone has four categories. ${ }^{54}$ Adjustments are then made to the benchmark prices based on location (such as major and medium squares (h?.q१,, ), proximity and adjacency to streets, and other considerations). ${ }^{55}$

\subsubsection{Duration taken in the process of obtaining land and land titles}

After the tender process, a contract of urban land lease is concluded which states "construction start-up time, completion of payment schedule, grace period, rights and obligation of the parties" and other details. ${ }^{56}$ Down payment of the lease price is paid prior to the signing of the $\operatorname{contract}^{57}$, and lease holding certificate (that has the particulars stated in Article 17(2) of the Lease Proclamation shall be issued, and the delivery of the plot of the land shall be made after the contract. ${ }^{58}$

The duration needed in the process of obtaining land and land titles is, under the law, expected to be the logical culmination of the lease process. Problems in this regard are rather manifest in other modes of access to land. For the purpose of this chapter, it suffices to note that the challenges in the lease track rather relate to retaining the land owing to delay in construction, and the challenges in transferring urban landholding and using it as security for bank loans.

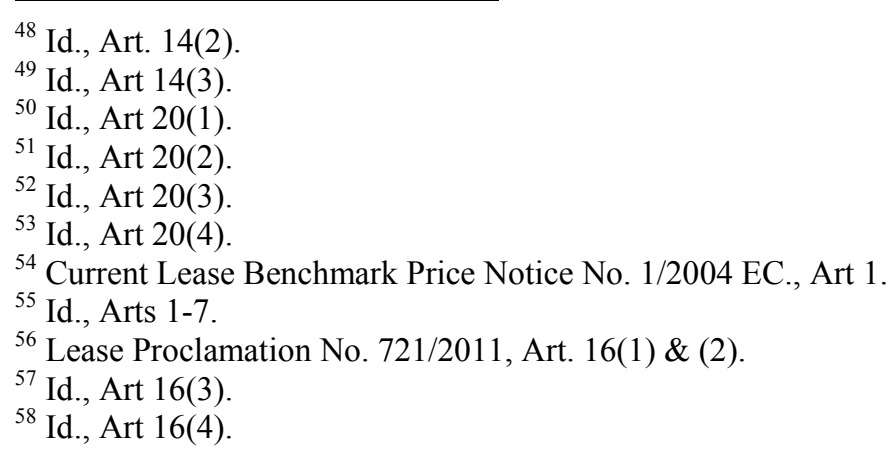




\section{Scope of Tenure and Its Security in Urban Land}

Although the words 'tenure' and 'security' are closely related, they have thematic variation. Tenure relates to the scope (breadth) of the rights over a given land. Private ownership on given plot of land (perpetual freehold) is, for example, a wider tenure than leasehold, because the latter, inter alia, involves duration. Security on the other hand, inter alia, refers to the level of guarantee or assurance that a person has over a specific tenure. The breadth of tenure may not necessarily guarantee stronger security if, for example, administrative authorities are entrusted with wide discretionary powers to reallocate landholdings without judicial review. A country that has such legal regimes and institutions is said to have weak tenure security.

Access to land, inter alia, relates to the scope of tenure (duration and breadth of the right) and also relates to the security of landholding and immovable property ownership which include guarantee against infringements, efficient and transparent registration of real rights, transferability and the right to use land as security for bank financing. Tenure security motivates investment and enhances the supply side of business premises in the urban landed property market (on rent or sale). In the case of modern farming, for example, tenure security facilitates the pursuance of sound land management and environmental protection because the level of tenure (use and control including scope and duration) and security of landholding are among the core factors that enhance or adversely affect land management. ${ }^{59}$

\subsection{Duration of urban land lease}

According to Article 18(1) of the Lease Proclamation No. 721/2011, "[t]he period of urban land lease shall vary depending on the level of urban development and sector of development activity or the type of service" and shall have the ceiling of 99 years for residential housing and the activities and entities stated under Art 18(1)(a)(1). ${ }^{60}$ The same ceiling of 99 years applies for education, health and sports in all Ethiopian urban centres. ${ }^{61}$ Pursuant to Article 18(1)(b), the ceiling of the period in Addis Ababa shall be 70 years for industry, 60 years for commerce and others. Article 18(1)(c) raises these ceilings to 80 and 70 years respectively for urban centres other than Addis Ababa. The lease

${ }^{59}$ See for example, ECA (2004), "Land Tenure System and Their Impacts on Food Security and Sustainable Development in Africa", Economic Commission for Africa report no. ECA/SDD/05/09, Addis Ababa. Also see Gershon Feder and Tongroj Onchan (1987), "Ownership Security and Farm Investment in Thailand," American Journal of Agricultural Economics 69, No. 2.

${ }^{60}$ In addition to residential housing, the list includes science and technology, research and study, government offices, charitable organization, and religious institutions.

${ }^{61}$ Lease Proclamation No. 721/2011, Arts. 18(1)(b)(1) and 18(1)(c)(1). 
ceilings stated in Article 18(1) "may be extended for a lease period of time of not more than half of the specified ceiling for a development activity or service requiring an extended period". ${ }^{62}$ Extension of the lease period (Art 18/2/a) refers to extending the ceiling for the period of lease while renewal envisaged under Article 18(2)(b) last sentence and Article 19 refer to the renewal of the lease contract with a new landholding lease term.

Short-term lease periods of five-years ${ }^{63}$ are allowed under Article 18(2)(b) of the Lease Proclamation "to short-term economic and social activities intended to be carried out on urban lands not designated for immediate development use." The lease period may "be renewed for the same period of time [i.e., five years] where it is necessary." Article 23(2(a) of the Urban Land Lease Regulations No. 49/2004 EC, classifies urban agriculture as short-term lease while Article 18(2)(b) of the Proclamation clearly gives a threshold of five years for shortterm lease. As the Regulations cannot amend the Proclamation, urban agriculture can be regarded as medium-term lease rather than short-term lease.

The issue of renewal for long term lease periods is addressed in Article 19 of the Lease proclamation which provides that "The period of lease may be renewed upon its expiry on the basis of the prevailing benchmark lease price and other requirements" subject to the condition that "the lessee may not be entitled to compensation where the lease period could not be renewed." Although Article 19 of the Lease Proclamation does not expressly guarantee automatic renewal of leasehold upon expiry of the lease term, its reading leads to the presumption of renewal. A case in point for such presumption is Article 19(3), which requires the appropriate body to notify its decision to the applicant in writing "within one year from the date of submission of the application". According to this provision, such failure by the appropriate authority to communicate its decision "shall be deemed as though it has agreed to the renewal request ... on the basis of the prevailing lease price." Yet express statement in the law about automatic renewal based on prevailing benchmark lease price can enhance investor confidence.

In the context of the urban environment, buildings may be demolished and rebuilt by the owners themselves in periods of five or more decades (in the pursuit of comparative economic advantage by upgrading the premises). Thus, it is not the ceiling in the period of lease (e.g., 99 or 70 years), as such, that is of crucial importance, but the influence that it has on the values and interests of investors who usually have adequate means to fulfil their lifetime subsistence needs, but tend to look ahead toward the economic security of their descendants or other concerns into posterity such as endowments and trusts. In settings

\footnotetext{
${ }^{62}$ Id., p. 18(2)(a).

${ }^{63}$ Urban agriculture is regarded as short-term lease.
} 
where the usage of the nomenclature 'land lease' is merely nominal, end of the lease period is followed by automatic renewal, as a result of which negative perceptions of insecurity are rare; but if the level of state interest is very high in obtaining as much income as possible in lease right allocations, leaseholders may tend to consider the duration of the lease period as the end of their tenure.

Under public ownership of land, the landholder is not 'mere holder' in the narrow definition of the term ${ }^{64}$, but is co-owner of the land as a member of the public. The landholder thus holds what he/she co-owns with other members of the public. Unlike the narrow definition of the term, he/she does not hold the land on behalf of another party but under the mental element (animus) of owning the use rights. The duration of leaseholds is thus expected to be merely procedural that represents temporal signposts of renewal as opposed to a rigid and mechanical exit point of landholding. Automatic renewal without auction upon payment of basic lease rates for the location during the time of renewal is thus a matter of equity, justice and efficiency.

For example despite China's pledge to communism, Article 149, first alinea, of China's 2007 Property Law ${ }^{65}$ provides: "The term of the right to the use of land for building houses shall be automatically renewed upon expiration." Article 22 of China's Urban Real Estate Administration Law clarifies the procedures of renewal which require application for renewal for extension 'at least one year before the expiration of the term'. This provision states that "The application shall be approved except that the tract of land needs to be taken back out of public interest consideration". ${ }^{66}$ World Bank report in support of automatic renewal reads:

As one of the main effects of property rights is to increase incentives for investment, the duration for which such rights are awarded needs at least to match the time frame during which returns from possible investments may accrue. Clearly this depends on the potential for investment, which is higher in urban than in rural areas. While indefinite property rights are the best

${ }^{64}$ See Articles 1141 and 1147 of Ethiopia's 1960 Civil Code regarding the narrow definition of 'holder' as a person who holds a thing on behalf of another person.

65 The Property Rights Law of the People's Republic of China, adopted at the 5th Session of the 10th National People's Congress of the People's Republic of China on March 16, 2007, and effective on October 1, 2007.

66 "Urban Real Estate Administration Law of the People's Republic of China (adopted by the 8th meeting of the Standing Committee of the 8th National People's Congress on July 5, 1994 and amended according to the Decision on Amending the Urban Real Estate Administration Law of the People's Republic of China which was adopted at the 29th meeting of the standing committee of the 10th National People's Congress of the People's Republic of China on August 30th, 2007)". 
option, giving long-term rights that can be renewed automatically is an alternative. ${ }^{67}$

\subsection{Registration process and titling system}

The Urban Landholding Registration Proclamation No. 818/2012 states the need to "realize the rights of Ethiopians to immovable property as provided under Article 40(7) of the Constitution and their urban land use rights. ${ }^{68}$ The preamble of the Proclamation further states that "registration of urban land has become a fundamental institutional requisite to generate reliable information" for various purposes, and in particular to give "security for the possession rights of citizens, and thereby accelerate economic, social and environmental development of cities". ${ }^{69}$ The significance of the Proclamation also includes minimizing disputing claims over landholding and immovable property, and enabling the possessor to use his property by establishing transparent and accountable working system and enhancing the efficiency of government services. ${ }^{70}$

With regard to landed property markets, the Proclamation is meant to serve as a "legal framework which is up-to-date, efficient, compatible with market transaction that facilitates registration of rights, restrictions and responsibilities relating to land and immovable property". ${ }^{71}$ The Proclamation states that registration and land information "enhance the contribution of land and immovable property to the development of free market economic system and to certify land and immovable property right" and ensure possession security. ${ }^{72}$ Moreover, the Proclamation underlines the need to "implement legal cadastre principles such as registration of possession, getting the consent of the possessor during transaction, making registration of possession open to public, clearly identifying the possession and the possessor through unique identification codes". It is with these purposes and raisons d'être in view that Proclamation No. $818 / 2012$ is enacted.

Article 4 states the objectives of the Proclamation as "ensuring uniform protection of landholding rights ..." and environmental development of urban centres by ensuring landholders' security of landholding right and recognition of title to immovable property by

\footnotetext{
${ }^{67}$ World Bank (2003), Land Policies for Growth and Poverty Reduction, A World Bank Policy Research Report (Oxford University Press), pp. xxii, xxiii.

${ }^{68}$ Urban Landholding Registration Proclamation No. 818/2012, preamble, para 1.

${ }^{69}$ Id., preamble para 2 .

${ }^{70}$ Id., preamble, para 3, read the Amharic version for clarity.

${ }^{71}$ Id., para 4.

${ }^{72}$ Ibid.

${ }^{73}$ Id., Art 4(1).
} 
certifying the right through registration". 74 The cadastre includes "a cadastral base map, parcel map and cadastral index map which show features of the surface of the land" ${ }^{, 75}$ and a document (in hard copy and digital form) shall be prepared for each parcel "specifying the right, restriction and responsibility of a person having a land use right". ${ }^{76}$ This involves the assignment of a unique identification code 77 and the legal cadastre "which shall be organized and kept in the registration institution, [and which] constitutes the primary evidence for landholding certification purpose". ${ }^{78}$ Each parcel of urban land "shall have a unique parcel identification code" 79 and a "parcel index map shall show the parcel's unique identification code, length, width, measurement, position and shape, parcel's address, neighbouring parcels, bordering roads, corner marks, coordinates, northern direction and scale". ${ }^{80}$

Landholding registration presupposes legal entitlement to the landholding which may be old possession or leasehold. Landholding Administration Services Directive No. 12/2004 EC El $^{81}$ issued by Addis Ababa City Administration regulates the procedures of land titling in Addis Ababa. Article 2.4 of the

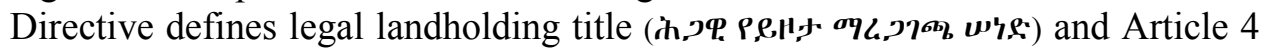
states the particulars stated in landholding and/or house ownership certificates. The Directive provides for the procedures involved in the issuance of landholding/house ownership certificates relating to individuals (Art 7), members of residential house cooperatives (Arts 8 to 11), condominiums (Art 12), real estate developers or persons who have received their house units from real estate developers (Art 14), and revocation of title deeds (Art 16).

Other issues addressed in the Directive include amalgamation and division of landholding (Arts 18 and 19), registration and removal of sureties and

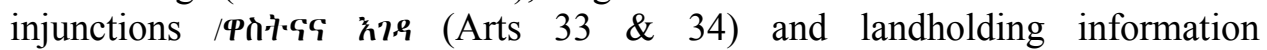
documentation (Arts 35-44). Moreover, Articles 20 to 28 deal with the transfer of landholding and/or house ownership due to sale, donation, bank foreclosure, judgment execution, privatization, substitution of membership in residential house cooperatives, transfer of ownership regarding condominium house units,

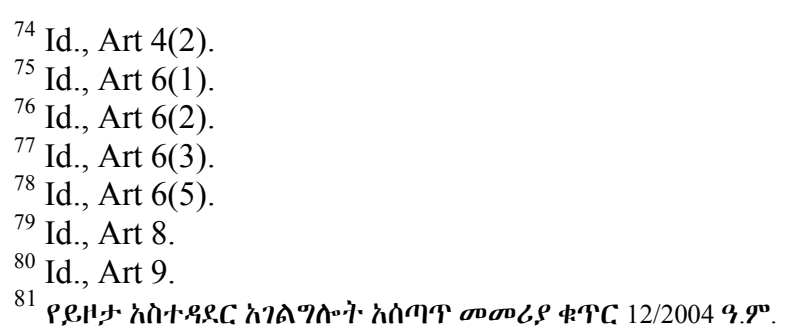


inheritance and title transfers from business organizations to individual persons and the vice versa ${ }^{82}$

\subsection{Transferability of leasehold, and the right to use leasehold as security for loans or for capital contribution}

According to Article 24 (1) of the Lease Proclamation, "a lessee may transfer his leasehold right of use, or [may] use it as collateral or capital contribution to the extent of the lease amount already paid." The scope of transferability is defined in Art. 24(2) which provides: "If a lessee, with the exception of inheritance wishes to transfer his leasehold right prior to commencement or half-completion of construction, he shall be required to follow transparent procedures of sale to be supervised by the appropriate body". In the event of such transfer of leasehold right, the proceeds of the transfer that can be earned by the leaseholder shall include:

a) "the effected lease payment including interest thereon, calculated at bank deposit rate"

b) "value of the already executed construction", and

c) " $5 \%$ of the transfer lease value". ${ }^{83}$

The remaining amount obtained from the proceeds of the leasehold transfer is paid to the appropriate public entity ${ }^{84}$, i.e. "a body of the region or a city administration vested with the power to administer and develop urban land". ${ }^{85}$

Likewise, there are restrictions regarding the amount of bank financing that can be obtained by using leasehold rights as collateral. Prior the commencement of construction, a leaseholder may use the land as collateral only to the extent of the amount not exceeding "the balance of the lease down payment after considering possible deductions to be made" regarding the penalty stipulated under Article 22(3) for failure to commence construction within the time specified under Articles 22(1) and 22(2) ${ }^{86}$ This restriction embodied in Article 24(4) of the Lease Proclamation clearly targets at combating against land speculation. However, it deals with the symptoms of land speculation rather than addressing the root causes of the problem. Moreover, it throws away 'the healthy baby' of enhanced supply of land-related rights along with 'the bathwater' of speculation which should have been addressed by dealing with its sources. Such provisions rather enhance simulations, underground deals outside

\footnotetext{
${ }^{82}$ Articles 29 to 32 of the Landholding Administration Services Directive No. 12/2004 EC deals with the taxes and service charges levied during these transfers of landholding or house ownership titles.

${ }_{84}^{83}$ Lease Proclamation No. 721/2011, Art. 24(3).

${ }^{84}$ Ibid.

${ }^{85}$ Id., Art 2(6).

${ }^{86}$ Id., Art. 24(4)
} 
the land-related open markets in which buyers conduct construction before landholding transfers. The restriction also causes rooms of corruption in the process of 'regulatory' threats, 'permissions' and favours for being 'colour blind' to simulated deals.

In the event of the default of the leaseholder in the performance of his/her contractual obligations of repaying bank loan, and where the default leads to litigation and judgment execution on the collateral, "the appropriate body shall, upon terminating the lease contract take back the land and settle the claim to the extent of the balance of the lease down payment" after retaining the deductions stated under Art. 22(3). ${ }^{87}$ Any remaining amount shall then be returned to the lessee. ${ }^{88}$ The measures that shall be taken against persons who are repeatedly engaged in such land speculation are stated in Article 24, sub-Articles 7 and 8.

Article 24(6) of the Proclamation waives such restrictions for constructed buildings and their accessories, and the provision recognizes the transfer of land use rights to the buyer of an immovable property where the immovable built on leasehold and its accessories are subject to collateral or transfer. The policy behind the restrictions thus clearly targets at controlling land speculation rather than denial of the economic value of land use rights if there is an immovable constructed on the land. This is, however, inconsistent with the various laws on expropriation and compensation which deny economic value to land use rights, ${ }^{89}$ and in the event of expropriation and displacement the latter prevail because they are specific laws directly applicable against displaced persons.

Article 24(6) is silent regarding the right of a landholder to use his/her leasehold rights as capital contribution if there is an immovable property built on the land. Such capital contribution of land use rights is narrower in scope than total transfer through sale because the landholder retains a share in the stock of ownership. It also enables financial resource to be directly used for construction rather than land-use right purchase. Thus, as long as Article 24(6) of the Lease Proclamation allows transfer (e.g. through sale), the juridical act of using the leasehold as capital contribution should not, for a stronger reason ( $a$ fortiori) be denied. The paradox in this regard is that a person who has a house on leasehold usually contributes it as capital so that a multi-storey building can be constructed thereby demolishing the immovable owned by the landholder. In effect, the capital contribution actually relates to land-use rights, while the legal fiction simulates as if the capital contribution refers to the immovable on the

\footnotetext{
${ }^{87}$ Id., Art. 24(5).

${ }^{88}$ Ibid.

${ }^{89}$ See Elias N. Stebek, Muradu Abdo \& Hailu Burayu (2013), "Property Rights Protection and Private Sector Development", PSD Hub Publication No. 23 (Property Rights Development Hub, Ethiopian Chamber of Commerce and Sectoral Associations, Addis Ababa).
} 
land. This paradox does not justify denial of the right to contribute leasehold as capital, but shows the gaps created by various proclamations and regulations due to their denial of economic value to land use rights.

\section{Use and Consistency in Treatment}

Access to land in the context of economic activities is not an end in itself but a means toward using the land. Use involves compliance with the regulatory framework that determines construction permits, construction permit renewals, the manner in which the land can be used, the cost of construction of business premises and other compliance standards in construction and use. The efficiency of construction permits and construction cost facilitates access to land, while challenges in this regard such as delay and unreasonable procedures in construction permits (and construction permit renewals) and exorbitant cost of construction are impediments to access to land.

Consistency in treatment relates to the extent to which competitors are treated with fairness and impartiality in the course of access to land. Day to day observation indicates three major factors that can be used as indicators for the level of consistency in land-related markets of countries where there is a significant regulatory intervention. These are equal access to information, affordability -versus- price hike segmentation in favour of the economic elite (usually the nouveau riche), and thirdly the degree of corruption (mainly in the forms of bribery, bureaucratic resource capture and nepotism).

The optimal level of consistency requires efficient registration and transparency in access to land information. This renders the information accessible to the wider public which has the right to be informed about the availability of urban land lease in the market. The issue of affordability, inter alia, relates to land use prices. Unless the sources of land supply are diversified accompanied by raise in the amount of supply, a steady rise in prices is inevitable. And as land, per se, is inelastic, there is the propensity for accelerated rise in price as long as various variables widen the gap between demand and supply for land.

The higher the rate of price rise in lease tenders, the more difficult it becomes for many or most business activities to benefit from land-related markets. As there is yet the cost of the construction after acquiring the land, landholders consider not only the lease tender price, but also the prospective capital required for construction. Depending on the locations of the parcel and its proximity to the central parts of the city or their adjacency to the main streets, the construction cost for the required number of floors becomes unaffordable to most members of the business community. As the height of corporate culture in many developing countries is modest, pooling in financial resources can hardly catch up with these challenges. This does not, however, mean that efficiency 
should be neglected in the guise of affordability, but there is the need for caution against land speculation by the nouveau riche which is in possession abundant wealth amassed from resource capture.

Private sector development organically develops from grass roots economic empowerment with a broader economic base which is conducive for the emergence and coalescence of wider middle class and for the ultimate alleviation of poverty. As John Rawls notes, there should be liberty and equality of opportunities, but he believes that even if economic inequality becomes inevitable, the interest of the disadvantaged should not be neglected. ${ }^{90}$ In other words, the disadvantaged should benefit from the outcomes of economic activities through benefits such as job creation, real income from employment and tax revenue. Equally important is the factor whether the economic inequalities are deserved owing to variation in efforts, work ethic, saving, entrepreneurship, competence and other legitimate income.

\section{Challenges in accessing urban land for business in Ethiopia}

\subsection{Challenges relating to monopoly in urban land supply}

Property laws reflect property relations in a given society, and their impact depends upon their concordance or dissonance with the dynamics of the economic and social system. Urban land laws can become problematic when they, for example, "unduly pursue fragmented (rather than synthesized) merger of certain elements from [Marxist and free market] systems". ${ }^{91}$ A case in point is the urban land use rights regime in Ethiopia's various proclamations, regulations and directives, where "fragmented collation results from picking the 'administrative authority of land allocation' limb from the Soviet model and combining it with the 'land use rights market' element from the market economy model". ${ }^{92}$ The challenge in this fragmented collation is that the land

${ }^{90}$ John Rawls (1971), A Theory of Justice, (Harvard University Press).

The notion of "Justice" formulated by John Rawls embodies the First Principle of 'liberties for all" and the Second Principle of 'Justice as fairness' which envisages two conditions that should be satisfied to justify the possibility of social and economic inequalities:

- $\quad$ "first, they are to be attached to offices and positions open to all under conditions of fair equality of opportunity; and

- $\quad$ second, they are to be to the greatest benefit of the least-advantaged members of society (the Difference Principle)"

${ }^{91}$ Elias N. Stebek (2013), Role Conflict between Land Allocation and Municipal Services in Ethiopia”, Mizan Law Review, Vol. 7, No. 2, p. 279.

${ }^{92}$ Ibid. 
supply function of administrative entities becomes monopolistic if it is not accompanied by other significant sources of land-use supply.

In market economies, the legal regimes give more attention to empowering the economic actors and state intervention is confined to regulating the market. On the contrary, in the Soviet-model, the state plans and leads the economy under the belief that it benefits the working class which it claims to represent. In the Chinese post-mid-1980s model, the reform focused on economic policies prior to political reform, and state-owned enterprises are allowed to act with relative autonomy in a relatively free market, and they usually operate under rules of operation which apply to private economic actors as well. China's urban land law facilitates a dual track supply in the land market. While the state, as the custodian of publicly owned land, is one of the major actors in land supply, urban landholders encounter no restriction in selling, mortgaging and using their land use rights (referred to as ownership of land use rights in various Chinese laws ${ }^{93}$ ) as capital contribution.

As stated in the preamble of the Urban Lands Lease Holding Proclamation No. 721/2011, there is a steadily increasing "demand for urban land" ${ }^{94}$ This calls for addressing all the challenges that weaken the supply side of land use rights in the land-related market. The enhancement of the supply side necessitates addressing challenges in the tenure and security of urban land use rights and facilitating the ease and efficiency of their transferability. As land is inelastic, the sustainability or increase in its supply side over a given period of time represents not only primary leasehold assignments by municipalities but also private sales and resale.

\subsection{Challenges relating to access to finance through collaterals}

Article 24(6) of the Lease Proclamation provides, " $[\mathrm{u}]$ nless agreed otherwise, a building constructed on a leasehold and its accessories shall be subject to the collateral or transfer" where the land use right is made collateral or is transferred. Likewise, "the right to the use of land shall be subject to the collateral or the transfer where a building on leasehold and its accessories are used as collateral and transferred". In cases of transfer of the leasehold (under any circumstance), all contractual obligations assumed by the lease shall be unconditionally transferred "to the third party to whom the leasehold right is transferred". 95

This shows that leasehold is transferable through sale and can also be used as collateral for bank financing if the building shown in the construction permit is

\footnotetext{
${ }^{93}$ See Article 143 of China's 2007 property law, supra note 64.

${ }^{94}$ Proclamation No. 721/2011, para 2 of the preamble.

${ }^{95}$ Proclamation No. 721/2011, Art 6(8).
} 
complete. This provision is indeed positive to the supply side of the urban land market. However, one may raise the issue whether an owner of a multi-storey building usually opts to sell out his property. The response is usually in the negative (save exceptions like bankruptcy) because there is no reason why such persons incline to sell out their property as they can reap the benefits from rental income and other benefits that attract potential buyers. The potential for the impact of this provision in the enhancement of the supply side in the landed property market is thus minimal.

The significant positive contribution of this provision is not thus access to land that can be obtained by potential buyers, but access to capital so that the owners of buildings can use them as collaterals for bank loans. These buildings thus regenerate themselves by enabling owners to have more access to capital, enter into lease tenders, win bids, construct other buildings and then proceed along the same chain thereby leading to elite benefits rather than broad-based access to urban land which could have been beneficial to entrepreneurs at all tiers including the ones at small and medium levels. This anomaly occurs not because of allowing such properties to be eligible to bank loans, but owing to the gap in consistency by disallowing similar rights to access to finance for other groups of leaseholds.

\subsection{Challenges relating to transferability of land use rights}

It is mere legal fiction and 'procedural righteousness' that an investor buys a house, while in fact he/she intends to demolish it and use the land for constructing a multi-storey building. The property right that the investor buys is thus the land use right. Laws and policies are expected to base themselves on realities and truth rather than legal fictions and simulations. It is this fictitious foundation that renders the restrictions on lease right transfers (in the context of incomplete constructions, etc) problematic causing a complex hide-and-seek

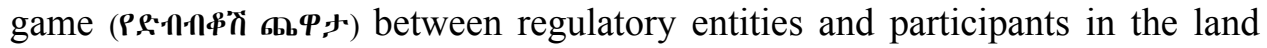
market which include sellers, buyers, brokers, and other actors in the process. As mentioned earlier in Section 2.3, the solution to the problem does not lie in restricting the transfer (and creating wider rooms of administrative discretion) but in addressing the root causes for market imperfections and deal with the core sources of windfall benefits from land use right resale.

Even after a lease tender, a vicious circle can start from delay in leased land development (such as infrastructure), investment permit, etc. which eats up the period of construction permit, construction start-up timeline, and then expiry of construction start up, renewal of lease, etc thereby entrenching arbitrary discretions. This rather enhances pressures and opportunities for corruption, speculation and nepotism. This challenge again appears in the preambles of newer regulations, directives and manuals, but unfortunately the grips of the newer laws may tighten up the wrong ropes and instead widen the avenue of 
discretion and arbitrary acts toward more entrenched corruption and rent seeking with enhanced levels of complexity and subtlety.

One may raise a question as to why a person who has won lease tender and has taken possession of the land cannot be allowed to resell it. The answer in the context of the Lease Proclamation and the subsequent regulations and directives can include three reasons related with the restrictions on the transfer of landholdings obtained from lease tenders and a fourth ground for special tenders. These reasons can be: (a) land is public property, (b) leaseholders should not reap big profit from public property, (c) it involves rent gathering and (d) there can be undue abuse of special tenders.

With regard to the first issue, the person is not selling land, but his right to the leasehold. The land remains public property, and the transaction merely brings in a substitute leaseholder in tender winner's place. The issue of reaping very high profit is not also tenable because such gap, in a few months, for example, merely indicates market imperfection which is usually attributable to the price and settings during the lease tender. A logical question that one can raise is "why didn't the person who offers a big price for the secondary lease buy the land use right at that price from the administrative entity in the first place?" This shows that the re-seller is selling his/her opportunity that was not available to a wider public, and this is the core feature of economic rent gathering. This calls for addressing the problems in the tender itself and in the land market rather than denying market value during the leasehold transfer.

In relation to the second reason of extreme 'benefit', one may forward counter-questions: 'so what, if the original acquisition was transparent and legitimate?' 'what if it was a lottery or other windfall income such as benefitting from exchange rate changes'? A person who takes this view feels positive about the benefit earned by a fellow citizen's earned and deserved economic benefits. After all, the seller's benefit trickles down to his family, relatives, tax income, prospective business activities, and so on. The more such benefits occur to different persons, the more would there be self-employment and dynamism in various economic sectors.

The third reason, i.e. rent gathering is indeed a valid ground as a wake-up call, but it rather requires caution against over-regulation and the tightening up of restrictions. Scarcity of resources and its aggravation through further restrictions are among the root causes in the creation of opportunities for rent seeking. This calls for addressing these root causes rather than quick-fixes on the effects. There is no reason why office holders whose decisions involve millions of Birr are not paid salaries commensurate with their position and inflation. Nor is there any reason why facilities such as government owned vehicles and rental houses are not availed for such positions. As long as the positions are deserved and merit-based, it is less likely that office holders betray their conscience in their decisions, because their competence, experience and 
integrity will naturally avail them with fallback settings even after they leave their positions.

The only valid ground for such restrictions can be the undue advantage from special tenders which becomes fraudulent if the beneficiary sells it to a party which will use it for purposes other than the ones that are entitled to special tender or short-term lease. This can be addressed by a regulatory restriction against the transfer of land use rights (obtained by allotment, special tender or short-term lease) for purposes other than the ones that were stated in the terms of the lease contract.

There can also be other fraudulent practices that may warrant interrogation into the former lease, rather than blanket restrictions on the transfer of leasehold or restrictions on collaterals as long as buyers are willing to pay a given price for the leasehold and banks are willing to offer loans based on the market value of the leasehold or incomplete constructions. In other words, the state is not expected to resort to price caps and loan ceilings, but focus on enhancing land supply through, inter alia, opening up interior lands within the city through road construction, street alignments, wider streets and other bigger projects, and by strengthening tenure security which positively enhances urban land supply.

\section{Challenges in the efficient transferability of rental business premises}

Businesses operate in dynamic environments. Access to land or business premises that are obtained at a given time may be underutilized or inadequate. Such settings necessitate transfer to the most efficient user, transfer to another premise, expansion or other changes commensurate with the objective realities that surround a given business undertaking. The prime objective of land space possession in business activities is the floor space utility provided by the land, working space or premise. If, for example, a certain portion of the floor space is underutilized, the extent to which a legal regime and administrative framework allows free transfer of such premises (in full or in part) clearly impacts on the business environment.

As land is physically inelastic, not all business firms can be owner occupants. Nor is it justified to restrict business premise transfers and, in effect, render convenient locations stay unutilized or underutilized, because such restrictions discourage transfer of business premises to their most efficient users. Under such settings, tenant-occupants rather opt to retain pubic or municipality-owned business premises upon payment of the modest rent which can be affordable. Even if assignments and sub-letting need normative regulations that protect the interests of the owners and neighbours, any restriction that cannot be justified under such grounds hinders the dynamism in business activities. 
Most business activities are conducted in rental premises. While the rate of increase in the supply of new business premises is one of the factors that can enhance the availability of business premises, the other source can be the ease in the transferability of business premises from persons who have rented the premises. Article 145(1) of the Commercial Code provides the following:-

Notwithstanding the provisions of Art. 2959 of the Civil Code, any provision in the contract of lease which prevents the lessee from assigning the contract of lease or from sub-letting the premises to the person that buys the business, or which makes such assignment or sub-lease dependent on the lessor's consent, shall be of no effect.

This provision envisages flexibility in the assignment and sub-letting of business premises. While assignment results in the entire substitution of the lessee of business premises, sub-letting enables the lessee (in the master lease) to retain his obligations with the lessor. The dynamic realities in business activities may require the assignment or sublease of the premises in case a certain business undertaking finds it difficult to use its premises for the duration of the lease term. That is why Article 145(1) of the Commercial Code embodies the right to assignment and subletting, as an exception to the restrictions under Article 2959(1) of the Civil Code which allows a contractual clause to prohibit subletting or to make such sub-lease conditional on the acceptance by lessor.

The Houses Administration Directive No. 34/2006 EC which was issued by the Ministry of Urban Development and Construction (in January 2014) has substituted an earlier directive issued (in November 2011) by the Agency for Government Houses. Unlike the 2011 Directive, the latter (2014) Directive allows a relatively wider room for the transferability of business premises. This is indeed commendable, and it is believed that the scope of transferability can further be enhanced in line with the spirit of Article 145(1) of the Commercial Code.

The Houses Administration Directive No. 34/2006 EC allows the transfer of the tenancy of a business premise upon the transfer of business as a result of inheritance, donation, sale or other contracts, privatization or judgment execution. However, Article 24(1) of the Directive provides that the rent to be paid by the new lessee shall be determined based on the highest rental rate used in the vicinity as can be observed from rental contracts concluded by the Agency for Government Houses.

The transfer of rights and obligations in relation with rental business premises envisages mere substitution of a tenant/ lessee (NhG., $)$ ), in such a manner that all other rights and obligations remain unaltered for the remaining period of the lease. If, for example, the period of lease is five years and the transfer occurs at the end of the second year, the rights and obligations of both parties are expected to be transferred unaltered for the remaining period of lease, i.e. three years. The Agency for Governmental Houses, is of course entitled to 
make rental adjustments at the end of the lease term. However, as the remaining period of lease relates to the rights and obligations that are transferred from the earlier tenant/lessee, the lessor should not have been entitled to alter the terms of the contract. This cannot be regarded as transfer of a contract, but transfer of the right to enter into a new rental contract. This scenario can only apply if the transfer is made upon the end of the rental period.

The original French version of Article 145(1) of the Commercial Code titled "Clauses interdisant la cession ou la sous-location" reads:

Par derogation a l'article 2959 du Code Civil, sont nulles les clauses d'un bail tendant a interdire au preneur de ceder son bail ou de sous-louer de locaux a l'acquereur de son fonds au a suburdonner cette cession ou cette socus-location a l'agreement du bailleur.

Unlike the English version, the French version does not use the word 'buys' but a wider word 'acquirer' (a person who acquires) thereby showing the wide scope intended by the drafter of the Code. The correct English translation of the original French Version of the draft should thus read as follows:

Notwithstanding the provisions of Art. 2959 of the Civil Code, any clause of the contract of lease forbidding the lessee from assigning the lease or subletting the premises to the acquirer of the business or which requires the consent of the lessor for such assignment or sub-lease shall be of no effect. ${ }^{96}$

Professor Alfred Jauffet who completed the drafting of the Commercial after Professor Jean Escarra's sudden death in August 1955, had indicated that the Code did not adopt the restrictions of the transfer of business embodied in some legal regimes. He also noted the attention given to the interests of the lessor, because the assignee or the sub-lessee cannot oblige the lessor to renew the contract of lease after the end of the lease term:

... I have eliminated some of the French rules which are perhaps too complex. ... Nor have I included the restrictive legal rules on renting businesses because the Codification Commission, whose advice I sought on this point, did not favour this restriction. Also on the advice of the Codification Commission, I have not included the right to renew the lease of business premises, thus eliminating what the French law calls 'commercial property; (proprietie commercial), a concept which gives rise to very detailed and changing legislation and to considerable case law. ${ }^{97}$

The scope of transferability of rental business premises envisaged under Article 145 of the Commercial Code enables business premises to be easily transferred

\footnotetext{
${ }^{96}$ The word 'acquirer' (l'acquereur) is used in the French version.

${ }^{97}$ Alfred Jauffret, General Report: Book I of the Commercial Code (1, March 1958), in Peter Winship (trans). Background Documents in the Ethiopian Commercial Code of 1960, Artistic Printers, Addis Ababa: 1974), p. 52.
} 
to the most efficient user, and it relieves lessees from onerous cost and potential loss in the event of financial difficulties. While the ease of transferability encourages decisions toward access to rental business premises, restrictions, on the contrary, discourage risk taking and entrepreneurship due to the potential risk of shying away from relatively long rental periods.

\section{Rising Prices and Concerns of Affordability}

\subsection{Push factors toward the escalating demand for own business premises}

There is an escalating demand for owner-occupancy among many businesses in Ethiopia, and meanwhile house rent is steadily rising in Ethiopia's urban centres. The steady increase in residential and business premise rental rates in Addis Ababa is a case in point. Day to day observations, show that various factors prompt urban residents in general and businesspersons in particular toward rush to owned houses. This trend can be attributable to factors such as (a) the steady rise in house rent, (b) the expectation that real assets steadily appreciate in value, (c) the belief that real property is safe haven against rising inflation contrary to saving accounts whose interest rates can be lower than the pace of inflation, (d) the relatively 'safer' and easier return on investment as compared with other avenues of investment, and (e) the lower susceptibility of rental income to unexpected tax assessments.

Business environment involves a number of internal and external factors some of which are outside the control of business persons. External factors can be conducive or prohibitive to vital economic activities such as modern farming and manufacturing. While certain resources such as capital can be borrowed or imported through Foreign Direct Investment, there are factors that are intrinsically endogenous, including the institutional features of a given setting such as governance, legal regimes, level of corruption, work ethic, and other factors.

For example, economically strong competitors who dump identical products into markets through 'obscure' stores and invisibly-protected 'import' channels to the detriment of local manufacturers, tax paying shops and law-abiding wholesale outlets make it difficult for the latter to compete, thrive and survive. The challenges then go downstream and waves of goods flood the streets and mini-boutique containers, thereby rendering a significant number of tax-paying shops and clean business unprofitable. As auctions and big transactions grow virtual, with façade shops and 'offices' as contact points, it can indeed become a challenge for ethical businesses and success stories of entrepreneurship in various spheres to prosper and for upright role models to take the lead. A case in point is the volume of expensive items (such as smart phones) that are being 
distributed to retail shops by peddlers carrying plastic bags. These challenges render clean and ethical business very difficult and costly.

The challenges include the inability of many clean businesses to pay rental bills, have access to prime business locations, or to effectively use their business premises if they are owner occupants. As the level of corruption and unclean business grows, the 'conscience dilemma' becomes pervasive thereby potentially leading to a widespread misconception which tends to consider 'good conscience' as 'naive' and honesty as 'unaffordable', while 'economic gains' irrespective of unethical practices and spiritual depravity are tacitly taken as being 'smart' and 'successful'. 'Business' permeated by corrupt oligarch godfathers can eventually crowd out many clean businesses including access to land and business premises. A case in point is an oligarch's ability to pay lease price irrespective of hikes thereby adversely affecting ease in doing business in the context of fair and law-governed competition among members of a broadbased business community.

Rental rates are among the factors that can hardly be managed by businesses that operate in rented business premises. A rise in house price naturally pushes up rentals during business start up and renewal of lease terms. An incidence in Addis Ababa, Berbere Tera (in the Merkato/ Teklehaimanot area) is a wake up call regarding the level of lease tender price hike bubbles that can occur in a highly imperfect market. Unlike the tulip bubbles of 1637 in the Netherlands ${ }^{98}$ such price bubbles relate to land and not a dispensable commodity.

It was on the turn of the Ethiopian Millennium [2007] that for the first time one square meter of a plot of land in the heart of Addis Ababa was offered a whopping 22,000 birr (USD 1,100 at 20 birr/dollar exchange rate). The plot was located in Kirkos sub-city, one of the prime locations in the capital city, Addis Ababa. At the time, this price caused a bit of a stir in the urban land-lease market and the economy in general. Nobody anticipated that but the worst is yet to come. From there on, the lease price of urban land

98 “... At the peak of the tulip mania in February 1637, tulip contracts sold for more than 10 times the annual income of a skilled craftsman, which was more than the value of a luxury house in seventeenth-century Amsterdam. ...

People were buying tulips at higher and higher prices, intending to resell them for a profit. However, such a scheme could not last because tulip prices were growing faster than income. As a result, the demand for tulips eventually collapsed and the bubble burst. The Dutch economy went into a deep recession in 1637. Although historians and economists continue to debate whether the tulip mania was indeed a bubble caused by what Mackay (1841) termed 'extraordinary popular delusions and the madness of crowds' ..., many observers believe that bubbles are important elements of real-world asset markets".

Pengfei Wang and Yi Wen (2012), "Speculative Bubbles and Financial Crises",

American Economic Journal: Macroeconomics, Vol. 4, No. 3 (July 2012), pp. 184, 185 
especially in Addis Ababa went into soaring spiral to reach 305,000 birr (USD 15,250) [in December 2014]. However, Zeway Trading Plc was not the only one that offered a price quote that would definitely make people raise their eyebrows. For the same plot, the second highest bidder offered 288,000 birr, both record-high in land market in Ethiopia. Granted, the plot was located in the heart of the business center of Addis Ababa and one of the largest markets in the continent - Mercato. ${ }^{99}$

Wudineh compares this price per square meter for a plot (of 449 square meters) with "the most expensive land-lease price in the world":

Looking at the current data published by New World Wealth, London is the most expensive city ranked by the average lease price of properties. According to this ranking, currently, 200 square meters apartment in central London costs some where in the neighborhood of USD 42,300. London, in fact, leads Hong Kong, the second expensive city using identical category for comparison, by 6300 dollars still moving away further from the others like New York, Geneva, Singapore and Paris, ranging in price from 30,000 to 24,000 dollars. ${ }^{100}$

As Wudineh notes, while all these prices of foreign cities reflect the price of properties on the land plus the market value of the land, the plot in Addis Ababa is bare urban land. He states the views of experts that the lease price plus the value of construction that will be invested on the land can make the lease tender price in Addis mentioned above "comparable with the most expensive cities in the world". ${ }^{101}$ The caveat the experts underlined, however, was that "the lease price considered in the rankings are average prices" while the price of Birr 305,000 per square meter in Addis is the maximum figure ${ }^{102}$ for the city.

Wudineh recalls the concerns of Ato Mekuria Haile, who was the City Manager of Addis Ababa City Administration when Birr 22,000 per square meter was offered for an empty plot of land. Ato Mekuria (who is currently the Minister of Urban Development and Construction) had then expressed his concern regarding the unhealthy price hike by stating that "the government's intention is to supply urban land at a fair price", he had also stated that the government does "not want investors to exhaust their investment capital buying land". ${ }^{103}$ Wudineh, notes that Ato Mekuria had expressed his expectations that the price hike to Birr 22,000 per square meter will not continue, while in fact the realities thereafter indicated otherwise:

\footnotetext{
${ }^{99}$ Wudineh Zenebe, The Reporter, 13 December 2014 (with contributions from Tibebeselassie Tigabu and Dawit Taye)

${ }^{100}$ Ibid.

${ }^{101}$ Ibid.

102 Ibid.

${ }^{103}$ Cited in Ibid.
} 
“32,000 birr per square meter was offered for a plot in Wello Sefer area by Mum Properties Developments PLC. That also caused a heated debate between commentators and the general public. But, it did not end there. In 2012 and 2013, another round of auction also attracted yet again high offers. In this, plots located behind Edna Mall, were offered a whooping 65,000 birr per square meter for a total 158 square meters plot. SNI Trading the winner of this auction was closely followed by ANA Construction whose offer was beaten only by 1,000 birr. The interesting part is all the relevant city administration bodies were all in sync when they say they do not intend for the plots to pick up such high prices". ${ }^{104}$

The lease price at Birr 305,000 per square meter will add up to " 136.9 million birr (principal lease price) plus a nine percent interest compounding to give a total payment amount of 300 million birr over the next 30 years, coming up to 10 million birr annual payment" and this as Wudineh comments (by citing experts) warrants caution against letting the land market "flirt with such high prices" 105 thereby rendering it a paradox as to what kind of investment on the land can match the economic return expected of such investment on the land.

It is to be noted that the lease price mentioned above, i.e. Birr 305,000 per square meter is an extreme hike and does not represent the general price per square meter in Addis Ababa. In fact, the winner of the lease tender ultimately refrained from concluding the contract of lease. Nor does this figure represent the lease price ranges in other Ethiopian cities. Yet, this is a wake up call against the side effects of land-supply monopoly by municipalities. In the absence of alternatives and diversification in the supply of land-related rights, such figures can steadily lead to the trend of 'rationalizing' price hikes that are significantly lower than Birr 305,000 per square meter but still, substantially high.

This figure can indeed legitimize lease price hikes. For example, in Addis Ketema, Woreda 08, (former Woreda 5 Kebele 06), there was an extra area of about 200 square meters which (according to a discussion with informants on August 31, 2015) is adjacent to the landholding of Siket International Private Limited Company's owner-occupant business premises under construction. The lease price went up and the plot was sold at Birr 355,550 per square meter. ${ }^{106}$ Siket International PLC had no choice but push up the tender bid up to this amount in light of its need. The question thus becomes whether municipalities should 'holdout' land by making use of their monopoly over land supply to the extent of squeezing out such exaggerated amounts as 'lease price'.

\footnotetext{
104 The Reporter, Ibid.

105 Ibid.

${ }^{106}$ The Reporter (Amharic), 26 July 2015. (Capital, 29 July 2015 sates the plot as 240 square meters, sold at Birr 355,555 per sq. meter).
} 


\subsection{Compound interest in lease tender debts}

There are views that the compound interest rate is the most crucial element regarding affordability. Proponents of this view suggest that the interest should be payable upon the maturity of each annual instalment. According to this view, if for example, the total timeline for the repayment of the instalments is ten years, the amount that is expected to be paid each year should be subjected to interest rates only starting from the date on which each annual payment is due.

Although this option sounds equitable and fair in terms of reducing the heavy debt which arises due to compound interest rates on the aggregate unpaid loan, it can have adverse impact on the efficiency of loan recovery from debtors who can afford to expedite the payment of the lease price. This option can thus induce debtors (who can afford to speed up the performance of their obligations) to delay payments until each instalment matures, in order to use the money for other income generating activities including savings (which can bring about interest). This calls for a balance between alleviating the onerous burden of compound interest while at the same time giving due attention to putting in place incentives toward the payment of instalments before their maturity date. There should thus be a corresponding scheme of aggregate lease price range with reasonable levels of variation based on the timeline for amortization of debt. In other words, there should be upfront payment terms and different instalment payment terms applicable for different durations so that customers can be encouraged to speed up the payment of the lease price.

The issue of affordability cannot be solely perceived from the dimension of compound interest rates because such views tend to dissociate the inseparable elements of the land lease price. The challenges that relate to affordability, inter alia, evoke issues such as ability to pay, potential economic return on investment (including the start-up time for income generation), amount of principal, interest rate, duration of payment, and grace period before starting instalments. Such variables should thus be taken into account holistically, short of which mere reference to compound interest can be misleading.

A person who has a saving account reads her balance on a given day as a package and she does not dissociate what she had initially deposited and the interest accrued. She can of course raise issues regarding the interest rate and look out whether other banks offer better deals. But the amount of saving she has on a given date is the aggregate which she reads from a bank statement. Likewise, the price of a house under mortgage is the total amount paid (which includes principal and interest) over a given period of time, and it may vary depending upon the duration of amortization, i.e. the period during which the debt is fully paid off based on fixed payment schedules of regular instalments.

The misperception of bidders for urban land lease about the compound interest thus emanates from the manner in which the benchmark price is 
publicized in the terms of the lease offer. The amount stated as the benchmark price dissociates the principal and interest involved in the lease price. It should have rather stated the benchmark price range per square meter for (a) upfront payment, and (b) instalments payable per month within $\mathrm{x}, \mathrm{y}, \mathrm{z}$ years. In the latter option, considering the aggregate of periodic payments as price will not be appropriate as it constitutes price plus compound interest for deferred payment.

For example, if we, for the sake of simplicity, use a simple interest rate of $9 \%$ (rather than compound interest), the upfront benchmark price of Birr 20,000 per square meter becomes Birr 29,000 if it is payable in five years. The same benchmark price becomes Birr 20,000 plus 18,000, i.e. Birr 38,000 in ten years. In case the debt is payable in fifteen years, the portion of the interest becomes Birr 27,000 thereby exceeding the principal (i.e. Birr 20,000).

The standard monthly instalments are merely divisions of the total price (principal plus interest) to the number of months within the period under consideration. While the five-year deal in our example requires a payment of Birr $x$ per month per square meter (under simple interest) for five years, the tenyear lease payment involves payment of Birr $x+y$ per month. The five-year deal has the benefit of lower total price while the second deal has the benefit of longer period of amortization (i.e. ten years). A person who affords to pay upfront on the day of the lease tender would have the best offer in terms of price level (Birr 20,000 per sq. meter) but is the most disadvantaged in terms of period of payment.

Compound interest rates for the same periods are higher than the simple interest rates illustrated above. For example, 9\% compound interest for every unpaid amount of Birr 2,000 until the last month of the instalment term is as follows:

\begin{tabular}{|c|c|l|c|c|}
\hline Principal & $\begin{array}{c}\text { Annual } \\
\text { Interest } \\
\text { Rate }\end{array}$ & $\begin{array}{c}\text { Number of times that } \\
\text { the interest is } \\
\text { compounded }\end{array}$ & $\begin{array}{c}\text { Number } \\
\text { of years }\end{array}$ & $\begin{array}{c}\text { Principal plus } \\
\text { interest during the } \\
\text { last month of the } \\
\text { payment period }\end{array}$ \\
\hline 2,000 & $9 \%$ & 1 (i.e. once a year) & 5 & $3,077.25$ \\
\hline 2,000 & $9 \%$ & 12 (i.e. each month) & 5 & $3,131.36$ \\
\hline 2,000 & $9 \%$ & 1 (i.e. once a year) & 10 & $4,734.73$ \\
\hline 2,000 & $9 \%$ & 12 (i.e. each month) & 10 & $4,902.71$ \\
\hline 2,000 & $9 \%$ & 1 (i.e. once a year) & 15 & $7,284.96$ \\
\hline 2,000 & $9 \%$ & 12 (i.e. each month) & 15 & $7,676.09$ \\
\hline
\end{tabular}

Source: Author's example

The solution to the challenge of affordability does not thus lie in the 'waiver' of compound interest (subject to the issue whether the rate is fair) as such, which is impractical, but by lowering the principal which determines the amount of the compound interest. As long as there is urban land scarcity, it becomes 
unrealistic to expect a land transfer office to push down the price while bidders offer for more. Lowering the principal is rather possible only by lifting the restrictions that suppress the supply side of real property.

The other possibility is lowering interest rates which may have knock-on effects of pushing down interest rates for deposits, thereby adversely affecting saving which determines the liquidity of banks and their capacity to finance loans including the ones involved in leasehold payment schedules. There is thus the need for real solutions to the issue of affordability by targeting at the entire sum of the lease price rather that the misleading path of dissociating the interest from the principal.

\section{Corruption in the Land Sector: Overview of World Bank Study (2012)}

World Bank's publication titled "Diagnosing Corruption in Ethiopia"107 was published in 2012 with foreword by the Commissioner of Federal Ethics and Anti-Corruption Commission of Ethiopia (FEACC). ${ }^{108}$ The seventh chapter of the study deals with corruption in the land sector. The findings show that corruption risks in Ethiopia are increasing in the land sector "because of a weak policy and regulatory framework surrounding land allocation, titling, and management". It states the "weaknesses in the legal framework" and the resultant "opportunities for asset capture by elite and senior officials as well as corruption in the implementation of existing land policy and laws". ${ }^{109}$ In this regard, the report notes that "[i]nstances of such corruption include the institutionalization of informal fees, officials' allocation of land to themselves or developers, and issuance of forged land documents". 110

The study identifies the following chain of activities in land management and administration:

- Policy formulation;

- Translation of policy into laws, regulations, and directives;

- Creation of institutions and capacity to implement policies and legislation;

- Deployment of mechanisms to implement policy and legislation (processes, procedures, manuals, and so on); [and]

107 Janelle Plummer, Editor (2012), Diagnosing Corruption in Ethiopia: Perceptions, Realities and the Way Forward for World Bank Group Key Sectors (The World Bank, Washington D.C.).

108 Id., Foreword by Ali Sulaiman, Commissioner, Federal Ethics and Anti-Corruption Commission of Ethiopia, p. xiv.

${ }^{109}$ Id., p. 10.

${ }^{110}$ Ibid. 
- Implementation of systems for monitoring and evaluation, which ideally should feed back into policy formulation. ${ }^{111}$

The findings show that "most corrupt activity in the land sector occurs at the implementation stage" and that "the level of corruption is influenced strongly by the way policy and legislation are formulated and enforced". ${ }^{112}$ The examples stated to show the influence of these factors include "the capture of state assets by the elite ... through the formulation of policy that favors the elite", "inadequate provision of resources to institutions mandated to administer land under generally sound policies" or "abuse of power where policy is weak or unclear". ${ }^{113}$ The findings of the study on key areas of corruption in the land sector are the following:

- "Capture of assets by the elite and senior officials. Elite capture is facilitated by a weak policy and legal framework and poor systems to implement existing policies and laws

- Corruption in the implementation of land policy and laws...

- Institutionalization of informal fees. The FEACC investigation of corruption in five sub-cities in Addis Ababa concluded that it was "nearly impossible to a get a plot of land without bribing city administration officials."

- Fraudulent actions of officials to allocate land to themselves in both urban and rural areas and to housing associations and developers in urban areas;

- Willingness of officials to defraud or respond to bribes or nepotism to overlook virtually all specified restrictions and requirements, particularly in Addis Ababa, which has seriously undermined the enforcement of land use plans, lease conditions, and building and construction codes in urban areas;

- Issuance of forged land documents resulting from fraud, bribery, or nepotism, which has seriously eroded confidence in the land records system". 114

The study notes the research report of the Federal Ethics and Anti-Corruption Commission of Ethiopia based on a household survey which states that "the customs service is the most corrupt sector, followed by land allocation, national housing, judges and the court system, and the tax system". 115 The study discusses the vulnerability of the land sector for corruption because land administration systems "typically include processes to manage public land, record and register private interests in land, assess land value, determine

\footnotetext{
${ }^{111}$ Id., Tony Burns and Kate Dalrymple, Chapter 7, Land Sector Corruption in Ethiopia, p. 285.

112 Id., p. 286.

${ }^{113}$ Ibid.

${ }^{114}$ Id., pp. 286, 287.

${ }^{115}$ Id., p. 300.
} 
property tax obligations, define land use, and support the development application and approval process". ${ }^{116}$

As Burns and Dalrymple duly observe, land, as an enormously valuable asset "is particularly susceptible to corruption and rent seeking" thereby creating "a significant opportunity for corruption on the part of those with the legal authority to assign, revoke, or restrict rights to it". ${ }^{117}$ They further note that incidences of case by case decisions, which necessitate delegation of authority at various levels "such as in the case of building permits or other restricted land uses" create opportunities for corrupt practices. ${ }^{118}$ "The acquisition, management, and sale of state-owned land" are also identified as settings that "create further opportunities for bureaucrats to generate and collect rents". ${ }^{119}$ Burns and Dalrymple identify "at least five elements, or thematic areas, in assessing vulnerabilities for corruption and land governance":

- "How property rights to land (for groups or individuals) are defined and enforced, and how these rights can be exchanged or transformed to support the wider objectives of economic growth and social equity;

- How land is managed, how land use plans and regulations are prepared and implemented, and how land is taxed;

- What is classed as state land and how it is managed, acquired, and allocated to private use;

- What is the nature and quality of property ownership information available to the public and how easy it is to access or modify; [and]

- How land disputes are resolved and conflict over land is managed". ${ }^{120}$

The Value Chain Analysis of Corruption Risks in the Land Sector is summarized by Burns and Dalrymple in a chart based on their comparative analysis of corruption in the land sector in various developing countries. The chart ${ }^{121}$ shows that the spectrum of manifestations of corruption in the course of (a) policy formulation and legislation whereby vested interests influence policy and legislation, (b) budget formulation and allocation which can, for example, be manifested by undue benefits by head office staff and collusion between procurement and suppliers, (c) corrupt practices in appointments to key positions, (d) corrupt practices in land allocation, and (e) corrupt practices in land certification and records management.

These corruption risks take series of features which may involve grand and petty corruption in land governance. As investigations of corruption in the land

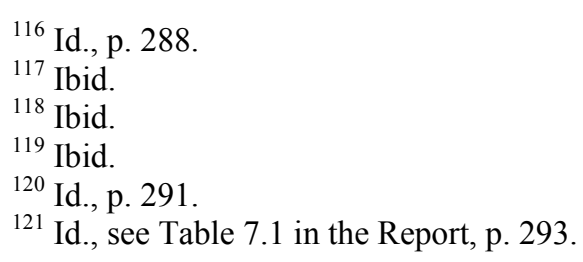


sector of various developing countries indicate, grand corruption can occur when, inter alia, there is "state capture, or the illegal conversion of state assets to private use where there are examples of corruption on a grand scale". ${ }^{122}$ The second category of corruption in land governance relates to "petty corruption or maladministration, including officials' solicitation (either directly or through middlemen) of illegal or informal payments in return for processing routine work or overlooking often ill-defined restrictions or requirements". ${ }^{123}$

The study uses Land Governance Assessment Framework (LGAF) which "is a diagnostic tool for the evaluation of the legal framework, policies, and practices relating to land policy, administration, use, and management". ${ }^{124}$ This tool has "a coherent set of 21 indicators and 80 dimensions" that are classified under the following five themes, namely (a) Legal and Institutional Framework, (b) Land Use Planning, Management, and Taxation, (c) Management of Public Land, (d) Public Provision of Land Information, and (e) Dispute Resolution and Conflict Management. ${ }^{125}$

The serious gaps identified with regard to the legal and institutional framework include "reliance on unpublished, easily changed directives" and lack of "real system to record rights and restrictions". The study notes that Addis Ababa's master plan plays little role in the city's development and that this "dysfunctional context has led to increasing corruption". ${ }^{26}$ It further states that the "master plan for Addis Ababa is being ignored, and most of the green areas and some of the roads in the master plan have been allocated for private use" in addition to which the "uncertainty in land documents and the issuance of forged land documents creates opportunities for fraud". ${ }^{27}$ The study states various areas of weak land governance identified by Multi-Talent Consultancy in 2010. ${ }^{128}$ These concerns related with weak land governance, inter alia, include unpublished directives, gaps in land registration, fragmentation and ambiguities in administrative mandates, gaps related to urban planning, and dispute resolution.

Burns and Dalrymple underline that the following key institutional and capacity issues are among the factors that create opportunities for corruption:

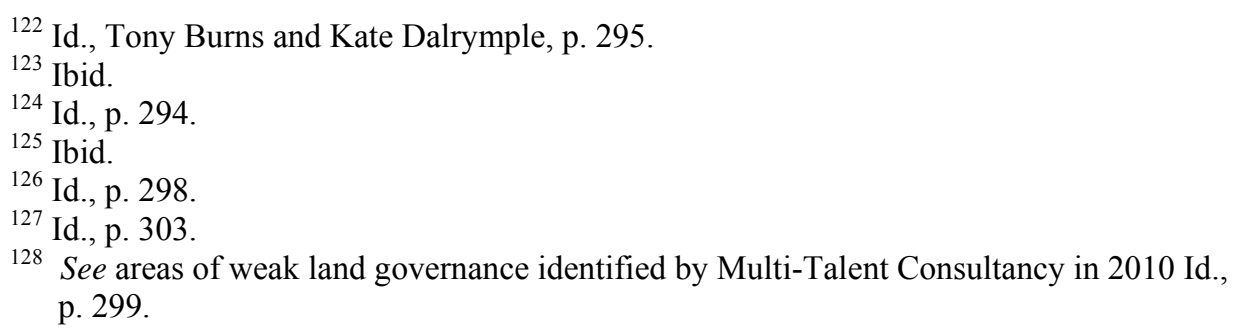


- "The broad delegation to unpublished directives, in the absence of a strong overarching policy framework, creates opportunities for discretion by officials.

- The lack of a clear, unambiguous mandate for the resolution of disputes creates opportunities for forum shopping and [it] fosters an environment where there is little consequence to illegal activity.

- The laws do not clearly provide for the appointment of independent lease board members, which creates conflicts of interest, reduces oversight of administrative activity, and creates opportunities for abuse of discretion". ${ }^{129}$

The short-term and long-term actions that are recommended in the study target at addressing the vulnerability of the urban land sector to corruption. The recommendations include the need for improving land governance, enhancing institutional strength, conducting pilot projects that can be scaled up to improve land allocation, and putting in place effective complaint handling schemes that enhance responsiveness. 130

\section{Observations on Various Clusters of Interest in the Private Sector}

In pre-capitalist socio-economic formations, members of the landed gentry in general and the aristocracy in particular benefit from the land law regime. In the course of social progress, land and other resources serve as inputs under capitalism during which a vibrant middle class takes the centre stage. Unlike Marxist versions of nationalization, the landed gentry is not denied of its ownership claims under capitalism, but is relegated to the back seat while entrepreneurs steadily widen access to land mainly through ground rent at the initial phases, and through assimilation with the newer generations of land owners in a steadily growing middle class. This class is not a small group of

${ }^{129}$ Id., Tony Burns and Kate Dalrymple, p. 308

${ }^{130}$ Id. Janelle Plummer, Introduction, p. 10.

- Improve land governance by developing a more comprehensive legal and policy framework.

- Strengthen institutions and systems throughout the land sector.

- Formally review the government's pilot to improve land allocation systems in four sub-cities in Addis Ababa (following the FEACC investigation) to deepen understanding and best practice, and then expand the pilot to other urban centers.

- Conduct similar FEACC investigations in rural areas and urban centers outside of Addis Ababa, given the government's positive reform following the previous FEACC investigation.

- Establish a regulatory body to address complaints and improve responsiveness to reduce corruption, perceived or actual, in Ethiopia's land sector". 
oligarchs, but a sector of the society constituted of achievers with commendable levels competence and integrity. This enables the middle class to gradually grow onto a wide social group that attains its economic status through innovation, diligence, saving, investment, productivity, social mobility and consolidation. This organic emergence and coalescence of the middle class was possible through the classical route pursued in various European countries such as Britain. Even if later-coming middle classes in USA, Germany and Japan sought various levels of protectionism from foreign industrial products, the legal regime on access to land pursued the classical route of market regulation through property rights protection, contract enforcement, etc., rather than state intervention in the supply side of land markets.

In later economic take-offs of South Korea, Taiwan and Singapore there were state interventions in access to land, finance, technology, enhancement of export potential and productivity. Yet, the interventions in access to land, for example, targeted at enhancing the supply side of land in the context of strong tenure security which did not lead to a predominantly mono-route state monopoly in the supply side of the land market.

Based on the informal discussion conducted with various members of the private sector in Addis Ababa whose anonymity is respected in this article and in light of careful observations on their overall positions, their views on access to urban land reflect varying needs, values and interests. Their views range from privatization of land (from an extremely liberal perspective) to various shades of regulatory interventions. These clusters of interest are not mutually exclusive. While some of the views are cross-cutting and shared by a certain portion of any group, the others usually manifest inter-group overlapping and co-existence.

This first cluster of interest which gives emphasis to liberalized land markets has parallels in history with regard to access to land during the emergence of industrialization. The classical setting during Britain's manufacturing boom in the $18^{\text {th }}$ and $19^{\text {th }}$ centuries did not need land allocation to widen access to land in favour of manufacturers. In fact, most entrepreneurs and industrialists rented land from landowners rather than investing their capital on land purchase and real property. The distribution of income (obtained from production) into rent, wages, interest and profit show the distinct inputs in the course of production of goods and services. The success or failure of private economic actors was not thus attributable to landholding, but to their productivity, competitiveness and management commensurate with the standards required in value creating and value adding economic activities. These internal factors were invariably accompanied by positive external factors such as macroeconomic policies and various elements of formal and informal institutions including the legal regime. Of course, access to land was among the crucial inputs. But it was sought from land rental and land purchase markets. The presence of many buyers and many sellers in the market that operated in the context of secure property rights and 
effective contract enforcement facilitated the market with minimum imperfections.

There are private businesspersons and academics in Ethiopia who favour such optimal privatization of urban land. Most adherents of this view consider it as an option that rectifies the current problems caused by the various counterproductive restrictions in Ethiopia's urban land law regime. At closer scrutiny, however, this option seems to be the anti-thesis to the current problems in Ethiopia's urban landholding markets. Even if this option cannot be ruled out as one of the viable courses of action in the long run, the optimal level of privatizing land in the Ethiopian context assumes an incremental approach through a pragmatic synthesis which avoids the pitfalls of abrupt laissez-faire privatization of land markets and the other extreme of paternalistic overregulation.

The second category of views relate to businesspersons who are uncertain about the duration of their public-owned business premise rentals. The monthly rental rates of public-owned business premises are far below the rates in the market. While these persons may not seek liberal policies such as privatization of the premises in which they operate or reinstatement of the property to its exowners from whom it was nationalized in 1975, they are critical of the legal regime which does not allow replacements or other options during dislocation due to urban upgrading or redevelopment plans. Their concerns in the event of dislocation are indeed legitimate, but it might seem unrealistic to expect regulatory offices to construct premises and allow rentals at the rate that prevailed until the date of dislocation. Yet, the good practices of municipalities that allow self-help redevelopment schemes can be win-win options which empower such businesspersons by making them owners of the commercial centres constructed by self-help schemes.

The issue of rented business premises evokes the third category of views as observed from business activities that are conducted in premises rented from private owners. For example, the rent of a private paints factory was Birr 10,000 in 2007 and was raised to Birr 40,000 after a few years. The premises were sold to another person who raised the rent to Birr 115,000 . The raise in rent was not due to the particular greed of the owner, but resulted from prevailing market imperfections. This is also the case in education institutions which are steadily raising tuition fees to catch up with the rise in rentals and other inputs. Economic actors in this category naturally seek access to land through allotment at benchmark lease rates. The challenge in this regard relates to the supply of serviced land, i.e. land which is availed with roads, electricity and water supply. Where land is available at reasonable rates, infrastructure is usually lacking. In effect, access to serviced land in good locations can be unaffordable to many economic actors due to high lease tenders and cost of construction at the standard required for the premises. 
The efforts of these businesspersons toward landholding target not only at usage security, but they also consider the ultimate market value of the immovable property that will be acquired. A typical example in this regard is a higher education institution which managed to own premises through purchase, and at some point rented out the premise and started conducting its academic programmes in premises rented at a relatively lower cost in comparison to the rental income it earns from its premises.

The fourth and fifth categories embrace a spectrum of groups engaged in services, manufacturing and real estate. These groups include different capital levels ranging from the relatively modest to the ones at the top in terms of financial resources and assets. Closer observations to these groups show a mixture of interests regarding access to land. The fourth group involves most private economic actors and it can be the foundation for an emerging middle class. In light of the challenges in usage security of rental business premises (stated above as the concerns of groups 2 and 3), many businesspersons strive to engage in premise construction through lease tenders or private purchase of land-use rights. However, they encounter various challenges including rising lease tender rates and restrictions in private landholding markets. Other challenges include steadily rising inflation, weak purchasing power of potential customers, extremely low-priced merchandise that floods the markets (including streets) through illicit and semi-illicit entry, and erratic tax burdens which give wide discretion for corruption and which adversely affect the tax base of the economy.

The fifth group includes a nascent (emerging) oligarchy of the nouveau riche (the new rich) which is in the process of ascending its 'dreamland'. For example, a person who wins four lease tenders at around the same time might manage to construct foundations and some structure in three plots, sell them and finish the building on one of the sites. Another example is reselling a plot of land with some structure at very high price many-fold its original lease price. The Urban Lands Lease Holding Proclamation No. 721/2011 was a reaction against such windfall rent gathering. But this over-reaction merely entrenches oligarchy by unduly suppressing the opportunities of access to urban land to the wider public and availing them to few who can outbid most private economic actors. The problems in the examples stated cannot be resolved by reinforcing restrictions in access to urban land (and transferability) because there are some who can comfortably meet the thresholds required in the Proclamation (such as $50 \%$ construction) if they opt to resell real property. The nouveau riche thus seem to be comfortable with the current urban land law regime because the mono-route supply fits to their ability to win bids and conduct construction. This easy ride enjoyed by this group clearly de-motivates responsible business firms in key sectors of the economy including manufacturing. 


\section{Conclusion: The Way Forward Beyond a Vicious Circle}

The preamble of the Lease Proclamation states the continuous and rising demand for urban land, the need for "a robust free market economy", and the need for "efficient, effective, equitable and well functioning land and landed property market". However, the Proclamation embodies series of restrictions (stated in Section 4) that negate the pledges made in the same Proclamation. The way forward thus requires harmony between the pledges stated in the preamble of the Proclamation and its real content. This calls for the unequivocal recognition of ownership of urban land use rights with well defined tenure security including accurate, current and readily accessible land registration and land information. Moreover, there is the need for clarity regarding automatic renewal upon expiry of the period of lease. The Challenges highlighted in Section 5, that adversely affect the transferability of land use rights and rental premises $^{131}$ also impede access to business premises.

The land lease price hike in Addis Ababa is indeed a wake up call because the sustainability of economic benefits for investors and the country at large does not lie in lease price figures per square meter. Nor do we benefit from the bulk of steel and concrete that hibernates in unfinished buildings thereby rendering enormous amounts of financial and other resources unproductive, and exposing the investors to compound interest rates of bank loans and foreclosure risks. In light of the level of corruption in the land sector (highlighted in Section 7), only second to customs administration, the way forward does not envisage restrictions on tenure security, transferability, security as collaterals and other avenues of access to land, but rather requires restrictions against the monopolistic role of municipalities in urban land supply.

In fact, municipalities should not at all have been involved in the land market because their role as leasehold seller contradicts with their municipal functions. ${ }^{132}$ Municipalities are custodians of urban plans which involve the protection of urban open spaces, green areas, parks, green belt around the cities and wide street networks, and these conventional municipal functions are clearly inconsistent with land banking for sale at lease tenders. The role of municipalities should have been effective provision of municipal services (including utilities such as water and electricity which are core elements in access to usable land) and effective municipal functions including the preparation and implementation of sound urban plans which are crucial for the

131 See PSD study, supra note 96, regarding the need for revoking all restrictions that narrow down the rights of assignment and sub-letting embodied in Article 145 of the Commercial Code.

132 See Elias N. Stebek (2013)," Role Conflict between Land Allocation and Municipal Functions in Addis Ababa", Mizan Law Review, Vol. 7, No. 2, pp. 241-282. 
efficient utilization of urban land though proactively planned transportation networks. Cases in point are the good practices in the infrastructural achievements such as Wollo Sefer, Bisrate Gebriel, and the Urael-BoleMedhanialem roads which transformed these parts of Addis in terms of urban development and access to land. It is thus the task of municipalities to open up the interior parts of Addis through such plans and infrastructure after which access to land and urban renewal would naturally ensue through thousands and millions of private minds, hands and resources.

Ethiopia's urban land law (which pledges to pursue robust free market economy as stated in the Lease Proclamation) in fact embodies land use rights that are narrower and weaker than the tenure security in China's property law, which pursues socialist market economy. Nor are the restrictions made in the Proclamation justified under the land property regimes of East Asian countries that (during the 1960s) pursued state interventionist policies of developmental statehood. These states had in fact empowered, and not substituted private economic actors. The way forward calls for drawing lessons from these developmental states with regard to access to land and tenure security.

Effective pursuits in addressing the severe scarcity in the urban land market in Ethiopia call for (a) thinking outside the box (lateral thinking), (b) proactively addressing the challenges through strategic (long-term) thinking, and (c) critically analyzing current problems (by identifying the elements and root causes) with a view to transposing the problems onto solutions. These patterns of thinking clearly show that land is inelastic, and it remains to be so even after the meager levels of green areas and open spaces in cities such as Addis Ababa are further dwarfed.

The Lease Proclamation, the Regulations and directives examined in this article attribute the various restrictions (in land use markets and land use right transferability) to the need to control rent seeking behaviours. Economic rent, inter alia, emerges from scarcity of a resource where it is accompanied by the discretion of administrative authorities to restrict, tighten or widen access to these resources. The resources may be land in the Ethiopian context, or may also include oil, minerals, etc. in various African countries. Under the current Ethiopian setting, rent seeking cannot be addressed by conferring more power upon administrative authorities, but by addressing the factors of corruption.

Cressey's ${ }^{133}$ triangle about factors of fraud, for example, indicates triadic and interwoven roots of corruption namely Pressures (i.e. Motivation or Incentives), Opportunities and Rationalization. The first factor, i.e. pressures to seek economic rent by an administrative officer can, inter alia, be related with an administrative officer's level of real income (net salary vis-à-vis prevailing

133 Donald Cressey (1919-1987). 
living expenses). The way forward in this regard calls for meritocratic appointments and substantial raise in salaries and benefits. Addressing the second factor, i.e. 'opportunities', inter alia, calls for land information that is current, accurate and readily accessible, and buttressing the supply side through broad-based and diversified suppliers of land use rights by setting aside the restrictions in the transferability these rights. And, the third factor, i.e., 'rationalization', among other things, requires demystifying the content of 'public ownership of land' and putting in place a clear and coherent policy framework which expressly recognizes the economic value of land use rights to which landholders can be entitled.

The nascent oligarchy highlighted in the preceding section is usually affiliated to corruption and land speculation which reinforce one another. This ultimately can lead to systemic corruption and state fragility thereby making it impossible to protect the elite's wealth if mass impoverishment disrupts peace, harmony, order and tranquillity. For the nascent oligarchy, the levels of discretionary power entrusted to administrative agencies in land allocation are sources of power and privilege. While bribery and nepotism hasten the nascent oligarchy's access to urban land, the rate at which lease tenders are rising can make it difficult to the lower and middle tier of economic actors to afford the rates and the cost of construction on key locations. The nascent oligarchy is thus comfortable with business as usual and in fact benefits from the restrictions discussed in the preceding sections because it is easier to obtain land from centralized land banks rather than scattered deals at market price with private landholders.

Although laissez faire land markets are susceptible to various problems that hamper development in the current Ethiopian and global context, the other extreme of over-regulatory paternalism is equally counterproductive. This necessitates avoiding both extremes and embracing an incremental approach which can start with setting aside most of the undue restrictions discussed in the preceding sections.

The way forward requires addressing the gaps in Ethiopia's urban land law toward the empowerment of broad-based private sector with particular attention to the grassroots. It is under such broad-based empowerment that economic actors with competence, entrepreneurial skills, motivation and integrity advance to the heights of success and competitiveness that they deserve. Indeed, this facilitates the emergence and coalescence of a strong middle class and tiers of achievers in lieu of an oligarchy that cannot be role model to the private sector nor serve the economic, legal and ethical dimensions of the private sector's business activities. Short of such pragmatic measures, business as usual by sustaining tight regulatory grips on access to urban land merely continues incubating oligarchs and enhancing corruption analogous to a dog's futile attempts to chase its tail thereby endlessly moving in a circle. 